\title{
PEMERTAHANAN BAHASA IBU TENTANG TEMPAT-TEMPAT SAKRAL DAN TANTANGAN \\ PERUBAHAN SOSIAL BUDAYA ORANG MARORI DAN KANUM DI KABUPATEN MERAUKE, PAPUA
}

\begin{abstract}
MAINTAINING THE MOTHER TONGUE ON SACRED PLACES AND THE CHALLENGES OF SOCIO-CULTURAL CHANGES OF MARORI AND KANUM PEOPLE IN MERAUKE-PAPUA
\end{abstract}

\author{
I Ngurah Suryawan \\ Jurusan Antropologi, Fakultas Sastra dan Budaya, Universitas Papua (UNIPA) \\ ngurahsuryawan@gmail.com
}

\begin{abstract}
Abstrak
Artikel ini memfokuskan pada penggalian bahasa ibu tentang tempat-tempat sakral bagi Orang Marori dan Kanum di Kabupaten Merauke, Papua. Bahasa-bahasa ibu bagi tempat-tempat sakral mengandung makna yang mentautkan hubungan manusia dengan lingkungannya. Masyarakat lokal memiliki pengetahuan kaya yang menunjukkan relasi panjang dengan lingkungan alam sekitarnya. Dari perspektif masyarakat terdapat pemetaan ruang-ruang hidup yang mencakup wilayah perkampungan, perkebunan, dan leluhur (pamali). Masyarakat juga menamai wilayah-wilayah tersebut dengan bahasa ibu yang biasanya mengacu kepada nama-nama tumbuhan, hewan, atau peristiwa sejarah penting di lokasi tersebut. Bahasa-bahasa tersebut memiliki makna yang luas dan menjadi cermin ekspresi kebudayaan orang Marori dan Kanum.Kondisi perubahan sosial budaya menghimpit mereka dan pondasi pengetahuan lokal dalam pemanfaatan lingkunga menjadi tergoyahkan. Masyarakat lokal memiliki pengetahuan kaya yang menunjukkan relasi panjang dengan lingkungan alam sekitarnya. Artikel ini menelusuri makna dibalik bahasa-bahasa ibu pada ruang-ruang hidup orang Marori dan Kanum. Pemertahan bahasa ibu menjadi sangat urgen di tengah perubahan sosial budaya yang mengakibatkan rusaknya lingkungan.Usaha tersebut tidak mudah di tengah mulai tercerabutnya akar budaya dan hilangnya pengetahuan bahasa lokal. Penghargaan terhadap lingkungan menjadi terabaikan dan perusakan berlangsung terus-menerus untuk kepentingan uang.
\end{abstract}

Kata kunci: pemertahanan, bahasa ibu, perubahan, sosial budaya, lingkungan, ruang-ruang hidup

\section{Abstract}

This article focuses on exploring the use of mother tongue on sacred places for the Marori and Kanum People in Merauke District, Papua. The mother tongue for sacred placescontains the meaning that links people's relationship with their environment. Local people have rich knowledge that shows long relationships with the surrounding natural environment. There are mapping of living spaces covering the village area, plantations, and ancestors (pamali) from their perspective of society. The community also names these areas in their mother tongue, which usually refers to the names of important plants, animals, or historical events at the site. These mother tounge have a wide meaning and mirror the cultural expressions of Marori and Kanum people. The condition of socio-cultural change hinders them and, moreover, the foundation of their local knowledge in the utilization of the environment becomes unsteady. This article explores the meaning behind the mother tongues in the living spaces of Marori and Kanum people. Mother tongue translation becomes very urgen amid socio-cultural changes that cause damage to the environment. The effort is not easy amidthe loss process of culture and knowledge of local languages. The efforts to protect the environment have been abandoned and the process of destruction has occurred continuously for the sake of economic interests.

Keywords: preservation, mother tongue, change, social culture, environment, living spaces 
"Kitong (kita) memikirkan anak-anak kita ke depan. Kenapa kita tidak bisa olah alam seperti saudarasaudara di Jawa yang bisa olah tanah. Kitong ke hutan-hutan terus karena dimanja oleh alam. Hutan $s u$ sediakan semua."

(Lukas Ndiken, tetua adat Marori di Kampung Wasur)

\section{Pendahuluan}

Sungguh banyak pengalaman yang saya dapatkan saat melakukan penelitian panjang di Kabupaten Merauke, Papua selama 2016-2017. Orang Marori dan Kanum yang menjadi subyek dari penelitian ini adalah sumber inspirasi dari sulitnya berjuang di tengah lingkungan yang sudah berubah. Keterhimpitan hidup secara sosial dan ekonomi di tengah kepungan pendatang dan juga cengkraman pragmatisme hidup bukanlah alasan untuk menjadi kalah. Kekalahan hanya akan menumpuk permasalahan lebih banyak, sementara di sisi lainnya diperlukan keputusan cepat untuk menanggapi perubahan yang ada di depan mata mereka. Perubahan sosial budaya ini tak terhindarkan, melanda manusia dan wilayah-wilayah kampung yang dulunya hidup dalam landaan filosofis lokal tentang relasi manusia dan ekologinya. ${ }^{1}$

Perlahan-lahan landasan filosofis ini mendapat tantangan dari pengaruh modernitas yang diangkut oleh berbagai kepentingan seperti migrasi yang kencang, perusahaan yang mengeruk kekayaan alam, dan akulturasi kebudayaan yang berlangsung halus dan berjalan mulus. Tidak ada yang salah dengan perubahan tersebut. Justru yang menjadi persoalannya adalah kemampuan refleksi terhadap masa lalu, kini, dan masa depan dari orang Papua serta menghadapi tantangan itu yang menjadi akar masalahnya.

\footnotetext{
${ }^{1}$ Artikel ini adalah bagian dari program penelitian yang didanai dalam skema Major Documentation Project, MDP0336 (2016-2017) dari ELDP (Endagered Language Development Project) SOAS London yang berjudul The Endangered Papuan Languages of Merauke-Indonesia: Ethnobiological and Linguistic Documentation. Terima kasih untuk Prof. Dr. Wayan Arka (ANU) selaku koordinator tim, Prof. Dr. Eko BarotoWaluyo (LIPI) dan teman-teman peneliti: Norce Mote, Agustinus Mahuze, La Hisa, Maxi, Petrus, dan seluruh narasumber di Kampung Wasur dan Kampung Tomerauw, Kabupaten Merauke yang membantu saya dengan cara mereka masingmasing sehingga tulisan ini bisa selesai.
}

Refleksi tersebut bersumber dari tanggapan yang dilakukan oleh orang-orang Papua terhadap perubahan sosial yang terjadi. Timmer (2013:22) mengungkapkan bahwa setidaknya ada dua hal penting yang mesti diperhatikan dalam konteks perubahan sosial tersebut yaitu: mobilitas dan transformasi. Kedua hal ini penting untuk menyangkal bahwa bahasa dan budaya Papua itu stagnan dan terlokalisir. Ia menunjukkan bahwa kajian budaya dan bahasa di Papua pada masa kolonial dan diwariskan hingga kini memperlihatkan adanya variasi yang tinggi. Hal ini mengundang kita melakukan reduksi untuk menarik batas dan menjelaskan karakteristik yang bervariasi tentang budaya dan bahasa di Papua yang eksotis. Pandangan kulturalisme ini sangat menyesatkan karena melihat orang Papua hanya ditentukan oleh budayanya sehingga budaya ini membentuk sebuah kesatuan organik yang utuh dan tertutup, sehingga orang Papua tidak dapat meninggalkan budayanya tetapi hanya dapat merealisasikan dirinya di dalam budayanya.

Salah satu unsur mobilitas dan transformasi orang Papua adalah relasinya dengan lingkungan. Berinteraksi dengan lingkungan adalah kehidupan orang Papua. Relasi manusia dengan lingkungan sekitarnya berimplikasi penting dalam konstruksi kebudayaan dan peradaban manusia. Oleh karena itu, begitu banyak pengetahuan lokal masyarakat yang tercipta hasil dari relasi manusia dengan lingkungan alamnya. Ilmu ekologi, yang mempertemukan manusia dengan alam, melibatkan totalitas imajinasi, pengetahuan, maupun politik pemanfaatan (baca: eksploitasi) terhadap kekayaan alam untuk kemakmuaran manusia. Pada titik inilah peran sentral manusia dalam dinamika hubungan dengan lingkungan alamnya menjadi penting untuk dicermati.

Jika menengok kajian akademik, fokus tentang relasi manusia dengan lingkungannya sebenarnya memiliki sejarah yang panjang. Sejarah itu berawal dari kajian yang fokus terhadap pengetahuan manusia tentang biologi termasuk di dalamnya pengetahuan tentang tetumbuhan (botani), hewan (zoology) dari lingkungan alam. Oleh karena itu, kemudian disebut dengan etnobiologi. Kajian etnobiologi telah menjadi suatu kajian lintas disiplin yang khas dan luas, baik secara teori maupun praktik. Misalnya kajian tentang jenis-jenis tumbuhan obat dan pengobatan tradisional, sistem 
keberlanjutan sumber daya alam, bencana alam. Perkembangan terkini biologi tidak lagi mengkaji sekadar aspek-aspek biologi atau sosial penduduk secara parsial, tapi kini kajian etnobiologi umumnya dilakukan secara holistik.

Kajian holistik yang dimaksudkan adalah kajian aspek-aspek sosial penduduk yang terintegrasi dengan sistem ekologi. Hal ini karena dalam pengkajian pengelolaan dan pemanfaatan sumber daya alam, seperti flora, fauna, dan ekosistem lokal yang dilakukan oleh masyarakat lokal menyangkut aspek-aspek sistem sosial dan ekosistem yang terintegrasi. Pemanfaat sumber daya alam yang terintegrasi dengan sistem sosial masyarakat diantaranya berhubungan dengan faktor pengetahuan lokal, pemahaman kepercayaan, persepsi dan world view (pandangan tentang dunia), bahasa lokal, pemilikan/penguasaan sumber daya lahan, sistem ekonomi dan teknologi, institusi sosial, serta aspek-aspek ekologis seperti biodiversitas, pengelolaan adaptif, dan penggunaan sumber daya alam berkelanjutan (Iskandar, 2016: 27-28).

Artikel ini secara lebih khusus memfokuskan pemertahanan bahasa ibu yang berhubungan dengan hubungan manusia dengan lingkungannya. Masyarakat lokal - dalam hal ini orang Marori dan Kanum di Merauke mempunyai pengetahuan lokal terhadap ruangruang hidup yang menjadi penyangga kehidupan keseharian mereka. Pengetahuan lokal tentang ruang-ruang hidup tersebut diwujudkan dengan bahasa-bahasa lokal. Oleh karena itu, sangat penting untuk melakukan dokumentasi bahasabahasa lokal tersebut untuk menjaga pengetahuan lokal masyarakat dan menegaskan pemahaman relasi kebudayaan antara manusia dengan lingkungannya.

Usaha dokumentasi bahasa-bahasa lokal, yang berhubungan dengan ruang ekologinya, sangat urgen dilakukan di tengah semakin terhimpitnya masyarakat lokal di tanahnya sendiri. Sumber daya alam yang menjadi penyangga kehidupan mereka dikeruk. Pengetahuan tentang manusia menjaga alam diterabas. Bahasa lokal yang menandakan hubungan tersebut beserta dengan nilai-nilai budaya di dalamnya perlahan redup tertimbun pragmatisme mendapatkan uang cepat. Arus-arus perubahan sosial budaya menyentuh langsung kehidupan orang Marori dan Kanum di kampung-kampung. Mereka menghadapi tantangan untuk menjaga alam, pengetahuan yang juga berarti bahasa lokal, di tengah keterhimpitan hidup.

Artikel ini mencoba menggambarkan usaha dokumentasi bahasa lokal Marori dan Kanum yang berhubungan dengan ruang-ruang hidup dan tempat-tempat sakral (pamali). Selain itu, artikel ini juga mengelaborasi makna dan pengetahuan lokal masyarakat dalam usaha mereka mengelola sumber daya alam. Bagian pertama akan menelusuri pemetaan kompleksitas dan konflik perebutan ruang-ruang ekologi, terutama yang berhubungan dengan konflik pemanfaatan sumber daya alam oleh perusahaan dan masyarakat. Bagian kedua mengelaborasi bahasa ibu yaitu bahasa Marori dan Kanum dari salah satu marga tentang ruang-ruang hidup mereka dan nilai-nilai yang terkandung di dalamnya. Bagian ketiga mendiskusikan tantangan perubahan dan situasi di tingkat tapak yang dihadapi oleh orang Marori dan Kanum di kampung-kampung. Merekalah di garis depan yang menghadapi para pemburu yang masuk ke wilayah-wilayah sakral hingga "tukang sensor" yaitu para pemotong kayu yang rela menerabas hutan bersama anak-anak muda di kampung. ${ }^{2}$

Berdiri di tong pu kebun adalah ungkapan lirih tetua Marori di Kampung Wasur, Lukas Ndiken, yang sedih melihat perilaku generasi muda mereka yang tidak lagi bekerja keras dan mengolah kebun. Generai muda ini untuk mendapatkan uang cepat memilih untuk memotong kayu bersama dengan "orang-orang kota" sebagai bos mereka dan tidak memperdulikan kebun. Lukas Ndiken berkeinginan agar anak muda Marori mampu untuk mengolah kebun menjadi kebutuhan hidup sehari-hari maupun menjualnya untuk mendapatkan uang. "Kitong harus berdiri di tong pu kebun. Mengolahnya. Tidak merusak alam tong $p u$ moyang."

\footnotetext{
${ }^{2}$ Artikel ini adalah pengembangan dari laporan awal saya yang berjudul "Dinamika Etnoekologi dan Transformasi Orang Marori dan Kanum di Kabupaten Merauke, Papua" (naskah belum diterbitkan) dalam program penelitian yang didanai dalam skema Major Documentation Project, MDP0336 (2016-2017) dari ELDP (Endagered Language Development Project) SOAS London yang berjudul The Endangered Papuan Languages of Merauke-Indonesia: Ethnobiological and Linguistic Documentation.
} 


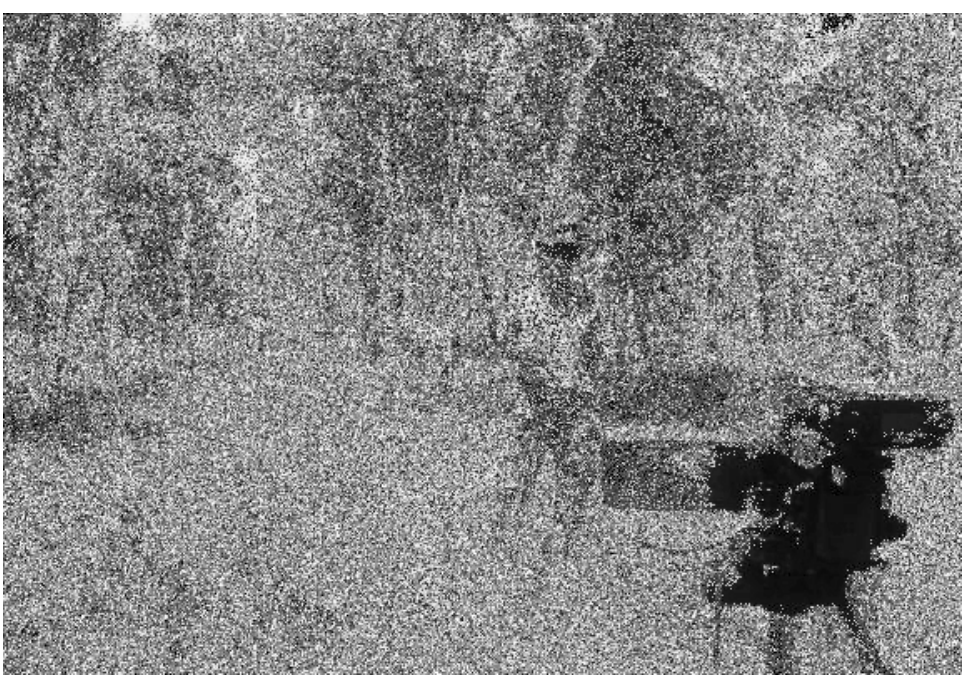

Gambar 1.

Pengetahuan Masyaraat Lokal Terhadap Lingkungan Sekitarnya Sangatlah Penting

untuk Didokumentasikan Sebagai Modal Sosial bagi Generasi Selanjutnya Menghadapi Perubahan Sosial

(foto: I Ngurah Suryawan).

\section{Terhimpitnya Ruang Hidup}

Harapan Lukas Ndiken akan semakin jauh dari kenyataan jika melihat peta penguasaan ruang-ruang hidup serta penyingkiran masyarakat lokal demi kepentingan investasi dan kapitalisme. Kondisinya sangat terancam. Ruang-ruang ekologi masyarakat semakin hari semakin terancam diambil oleh perusahaan yang merangsek masuk. Keterancaman tersebut bersumber dari tersingkirnya ruang-ruang hidup masyarakat lokal Papua yang tergerus kepentingan kapital maupun negara. Kapital yang berwujud masuknya perusahaan-perusahaan yang mengeruk kekayaan sumber daya alam mereka dan negara dalam bentuk terbentuknya wilayah-wilayah baru yang memerlukan tanah untuk pembangunan infrastruktur pemerintahan.

Salah satu kepentingan yang merebut ruang hidup masyarakat tersebut adalah kehadiran taman nasional sebagai wilayah konservasi lingkungan hidup. Orang Marori dan Kanum hidup dalam kawasan Taman Nasional Wasur di Kabupaten Merauke, Papua. Taman Nasional Wasur menjadi salah satu taman nasional yang menjadi penopang wilayah konservasi di Papua Selatan, khususnya di Kabupaten Merauke. Keberadaan Taman Nasional Wasur berada di kawasan wilayah Orang Marori, Kanum, Yeinan, dan Malind. Jika menengok kepada peraturan pemerintah, pada tingkat nasional pemerintah dinyatakan telah mengakomodir keberadaan masyarakat adat melalui UndangUndang Dasar 1945, Undang-Undang Nomer 5 Tahun 1990 tentang Konservasi Sumber Daya Alam Hayati dan Ekosistemnya, Undang-Undang
Nomer 41 tahun 1999 tentang kehutanan dan Undang-Undang Nomer 21 Tahun 2001 tentang Otonomi Khusus bagi Provinsi Papua. Dari keseluruhan peraturan tersebut pemerintah mengakui secara sah keberadaan masyarakat adat. Namun pada kenyataannya di lapangan, peraturan perundang-undangan tersebut belum diterapkan sesuai dengan hak-hak masyarakat adat. Sudah menjadi kenyataan sehari-hari jika masyarakat telah "kehilangan" ruang-ruang ekologi, tempat mereka menyandarkan hidupnya. Ruang-ruang tersebut telah tersematkan "wilayah konservasi" yang tidak lagi bisa dimanfaatkan.

Jika menengok ke belakang, konsep tentang konservasi dan terbentuknya kawasan konservasi itu sendiri sebenarnya adalah hal yang baru. Sebelum ide kawasan konservasi lahir, masyarakat lokal telah memiliki pengetahuan tentang menjaga sumber daya alam di ruangruang ekologi mereka sendiri. Pengetahuan tentang menjaga alam dalam perspektif konservasi masyarakat lokal harus dipertemukan dengan konsep-konsep konservasi yang dibawa oleh "orang-orang baru" dengan berbekal "kuasa" yang mereka miliki. Institusi-institusi yang mengembangkan pengetahuan tentang konservasi ini didukung oleh dana dan infrastruktur yang lengkap untuk mensukseskan idenya. Sementara di sisi lainnya masyarakat masih setia dengan pengetahuan mereka tentang lingkungan alamnya. Meski penuh tantangan, nilai-nilai tentang pengetahuan lokal-yang merupakan basis dari nilai-nilai konservasi-masih terpelihara di tengah masyarakat. 


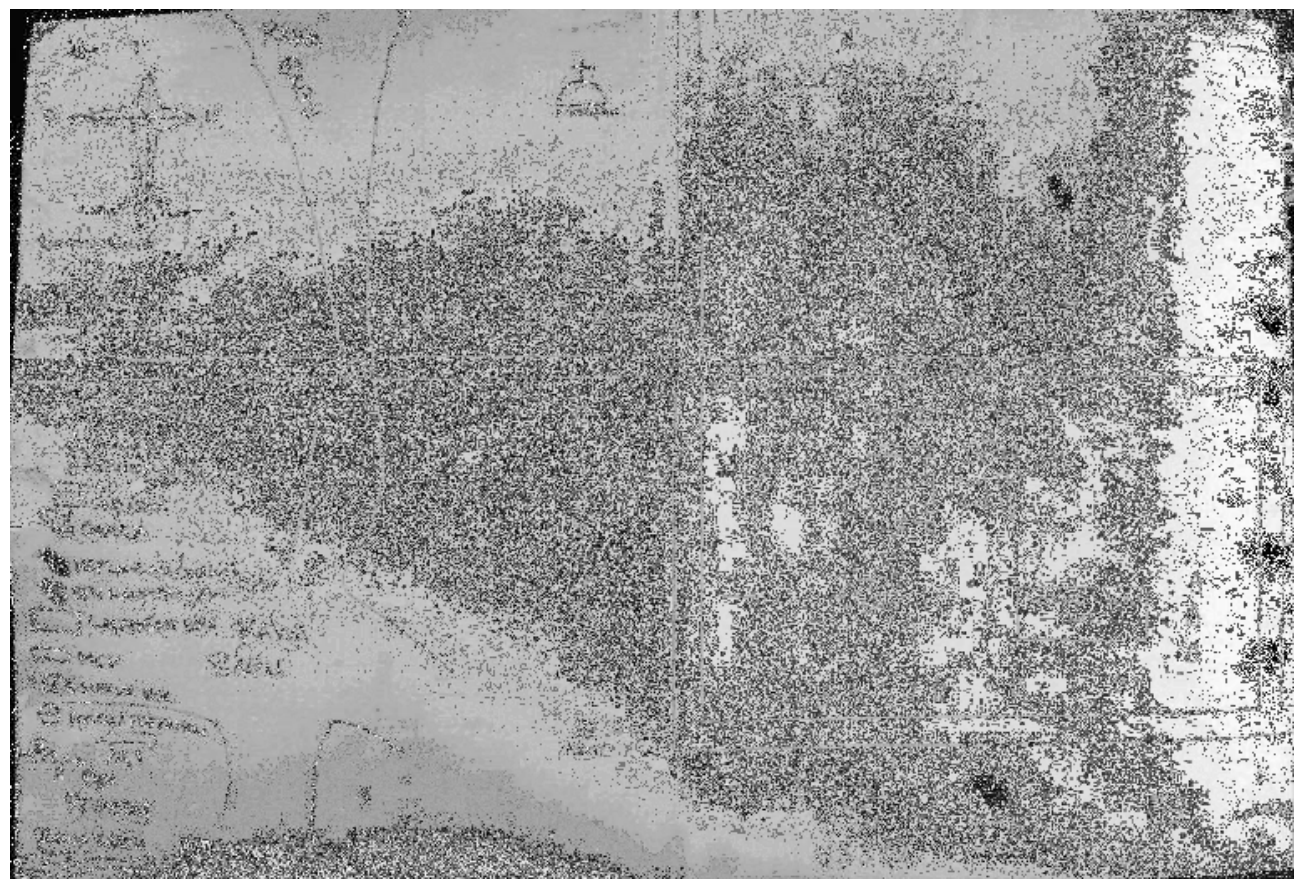

Gambar 2.

Peta Kampung Wasur di Kawasan Wilayah Taman Nasional Wasur (peta karya Lukas Ndiken)

Wilayah-wilayah konservasi yang berada di Kawasan Taman Nasional dalam konsep pembentukan awal pengelolaan kawasan konservasi selama ini telah mengabaikan keberadaan dan hak-hak masyarakat adat sebagai pemilik kawasan secara turun-temurun. Pemerintah telah menetapkan 527 kawasan konservasi dengan luas 27.190.992,91 hektar yang terdiri dari Kawasan Suaka Alam dan Kawasan Pelestarian Alam, di mana sebagian besar merupakan Taman Nasional (TN). Terdapat $24 \mathrm{TN}$ dari $50 \mathrm{TN}$ di Indonesia yang wilayah adatnya tumpang tindih dengan TN.

Taman Nasional Wasur yang berada di Kabupaten Mereauke, Papua, ditunjuk berdasarkan Keputusan Menteri Kehutanan Nomor 2882/ Kpts-IV/1997 tanggal 23 Mei 1997 dengan luas 413.810 ha. Taman Nasional Wasur dihuni oleh empat masyarakat suku asli yaitu Suku MalindImbuti, Kanume, Marori Men Gey dan Yeinan. Mereka telah hidup dan berdiam secara turun-temurun serta memiliki hak adat atas seluruh tanah dalam kawasan Taman Nasional Wasur. Taman Nasional Wasur merupakan wilayah adat dari masyarakat MalindAnim yang terdiri dari empat sub suku yaitu MalindImbuti, Kanum, Marori, dan Yeinan dengan marga mereka masing-masing. Masyarakat keempat suku ini memiliki aturan-aturan informal dan kearifan lokal dalam pengelolaan sumber daya alam di wilayah mereka.

Salah satu persoalan penting adalah eksistensi masyarakat lokal di tengah kawasan konservasi dan juga hutan adat yang menjadi milik mereka. Pada UU No. 41/1999 tentang Kehutanan disebutkan bahwa hutan adat adalah hutan negara. Undang-undang inilah yang menyebabkan tergerusnya hutan-hutan masyarakat oleh perusahaan yang didukung oleh negara dan perangkat kekerasannya. Intinya adalah yang diperlukan oleh rezim kapitalistik negara yang bekerjasama dengan otoritas negara hanyalah tanah saja, bukan manusia yang menempati tanah tersebut. Secara tajam, Tania Murray Li mengungkapkan bahwa "tanah dibutuhkan, tapi orang tidak!" dan "sumberdaya manusia dari Jawa didatangkan tanpa pelayaran balik" (Ramstedt 2011:42). Namun kini MK (Mahkamah Konstitusi) mengabulkan judicial review atas UU No. 41 tahun 1999 tentang Kehutanan. Ini artinya masyarakat adat memiliki kewenangan atas hutan adat dantidak ada lagi status hutan adat adalah hutan Negara. Dengan demikian, masyarakat lokal mempunyai hak secara sah terhadap ruang-ruang hidup mereka di hutan-hutan adat mereka. 
Ruang-ruang hidup masyarakat lokal lahir dan berkembang dari relasi mereka dengan lingkungan alam sekitarnya. Ruang-ruang ekologi inilah yang berperanan sangat penting dalam menciptakan totalitas kebudayaan manusia yang berhubungan dengan lingkungan. Hal lain yang tidak bisa dilupakan adalah bahwa ruangruang ekologi tersebut tidak bisa dilepaskan dari nilai-nilai kepercayaan terhadap nenek moyang, leluhur, dan tetua mereka sebelumnya. Oleh karena itu, terdapat wilayah-wilayah ekologi yang merupakan daerah pamali (terlarang), angker, dan dipercaya menjadi tempat sakral bersemayamnya para leluhur untuk melindungi generasinya.

Relasi manusia dengan zona-zona ekologi tersebut memproduksi nilai-nilai lokal berupa kepercayaan, pengetahuan-pengetahuan tradisional yang mereka yakini dan praktikkan dalam kehidupan sehari-hari. Oleh karena itu, di masing-masing zona ekologi selalu terdapat warisan pengetahuan dan jejak kebudayaan yang ditinggalkan. Ruang-ruang ekologi itulah yang menyangga kehidupan masyarakat di kampungkampung. Penyangga yang dimaksudkan adalah bahwa segala macam kebutuhan kehidupan mereka sehari-hari disediakan oleh alam yang mengelilingi mereka. Alam telah memanjakan mereka dengan berbagai kebutuhan. Alam adalah dapur mereka.

Sejarah panjang relasi timpang kuasa investasi global dengan masyarakat lokal menjadikan ruang-ruang ekologi masyarakat hilang dikubur perusahaan sawit, diterabas perusahaan kayu, bahkan digusur untuk perumahan para pekerja. Tidak ada yang mempedulikan. Akar sejarahnya lagi-lagi adalah ketidakjelasan penguasaan mereka terhadap tanah yang menjadi pondasi dan pertahan terakhir kehidupan mereka. Bisa dibayangkan bagaimana kelangsungan hidup mereka tanpa adanya penguasaan yang jelas atas tanah yang menyertai kelahiran, kehidupan, dan kematiannya kelak.

Rahman (2015:33) mengungkapkan bahwa pola-pola penyingkiran tersebut menjadi keseharian masyarakat di seluruh pelosok Indonesia. Ia dengan mengutip laporan dari Konsirsium Pembaharuan Agraria (KPA) menyebutkan bahwa sepanjang tahun 2014 saja sedikitnya telah terjadi 472 konflik agraria di seluruh Indonesia dengan luasan konflik mencapai 2.860.977,07 hektar. Konflik-konflik ini melibatkan sedikitnya 105.887 Kepala Keluarga (KK). Data KPA memperlihatkan konflik agrarian tertinggi pada tahun ini terjadi pada proyek-proyek infrastruktur, yaitu sebanyak 215 konflik agraria (45,55\%). Selanjutnya ekspansi perluasan perkebunan skala besar menempati posisi kedua yaitu 185 konflik agrarian (39,19\%), dilanjutkan oleh sector kehutanan 27 kasus $(5,72 \%)$, pertanian 20 $(4,24 \%)$, pertambangan $14(2,97 \%)$, perairan dan kelautan $4(0,85 \%)$ dan lain-lainnya ada 7 konflik $(1,4 \%)$.

Konflik yang disebutkan di atas tersebut akan terus-menerus meningkat seiring dengan massifnya perluasan kapitalisme melalui investasi. Sistem produksi kapitalisme ini menyebabkan porak-porandannya kehidupan rakyat dan tanah air yang berlangsung sistemik. Dalam proses penghancuran itulah dibutuhkan reorganisasi ruang untuk perluasan sistem produksi kapitalisme yang menghasilkan komoditas-komoditas global demi penciptaan keuntungan dan akumulasi modal perusahaan-perusahaan raksasa. Reorganisasi ruang tersebut termanifestasikan dalam berbagai bentuk ekspansi perusahaan-perusahaan berskala transnasional yang menyerobot tanah-tanah masyarakat lokal dengan perlindungan negara dan aparat keamanaan.

Kelompok-kelompok rakyat miskin di banyak desa, di pinggir kota, di dataran tinggi, di pedalaman, maupun di pesisir dari pulau-pulau, dilanda rasa risau dan kuatir sehubungan dengan ketidakpastian hak atas tanah, sumber daya alam, dan wilayah kelola kepunyaannya. Mereka adalah korban-korban operasi paksa pelepasan hubungan kepemilikan rakyat terhadap tanah, sumber daya alam dan wilayah, yang pada gilirannya berakibat lanjutan berupa perubahan drastic tata guna dari tanah, sumber daya alam dan wilayah, serta perubahan posisi kelas dari rakyat dalam hubungannya dengan keberadaan system produksi baru yang berdiri dan bekerja atas tanah, sumber daya alam dan wilayah itu.

Kebanyakan rakyat mengalah dan kalah dalam hubungan tersebut. Mereka menyingkir atau meninggalkan kampung halamannya karena tidak lagi bisa mengandalkan hidup dari tanah, sumber daya alam, dan wilayah yang telah dikapling perusahaan-perusahaan. Ada sedikit saja rakyat yang berhasil mempertahankan diri dan menghalau perusahaan-perusahaan yang mengkapling tanah-tanah mereka itu. Pola penyingkiran ini berlangsung terus-menerus tanpa adanya pemihakan dari negara. Penyingkiran manusia dalam ruang-ruang ekologi tersebut 
berada dalam naungan rancangan besar kapitalisasi, untuk kemudian memudahkan masuknya mesin kuasa kapital berbentuk perusahaanperusahaan yang mengeruk kekayaan sumber daya alam masyarakat. Penguasaan sumber daya alam tersebut mendapatkan dukungan kaki-kaki tangan lokal yang merupakan masyarakat di kampung-kampung yang membutuhkan uang untuk kelangsungan kehidupan mereka. Tanpa berpikir panjang mereka dengan sangat gampang untuk menjadi pemburu dan pegawai sensor kayu untuk kemudian dijual kepada para bos mereka yang berada di kota.

Kasus-kasus empiris dari cengkraman kapitalisasi yang menyerang kampung-kampung Papua menunjukkan adanya kepentingan yang lebih besar dalam usaha penguasaan sumber daya alam. Kepentingan tersebut bernama kapitalisme yang berusaha untuk menjadikan seluruh tanah dan sumber daya alam yang berada di Papua menjadi hak milik dari perusahaan dan bisa dimanfaatkan untuk meraih keuntungan yang sebesar-besarnya. Logika kapitalisme ini berlangsung massif dan menyerang seluruh wilayah-wilayah di Papua tanpa terkecuali.

Realitas yang terjadi di tanah Papua menunjukkan bahwa cengkraman kapitalisasi sudah sampai ke kampung-kampung sehingga tidak ada pilihan lain bagi orang Papua untuk menghadinya. Oleh karena itu, yang terjadi kemudian adalah pilihan konsumtif untuk mengikuti kemajuan yang disediakan oleh kapitalisme. Salah satu contoh yang gamblang jika kita menjejakkan kaki di kampung-kampung Papua adalah penggunaan telepon genggam (handphone) meski tidak hanya signal telpon dan kencanduan anak-anak muda untuk mengkonsumsi minuman keras (miras) hingga ke kampungkampung. Kondisi inilah yang memberikan peluang untuk bertumbuh kembangnya mesinmesin modal hingga ke kampung-kampung.

Dorongan pokok yang membentuk dan menggerakkan mesin kapitalis sesungguhnya berasal dari kemampuannya membuat rakyat mengkonsumsi barang-barang yang baru, yang kemudian melalui cara-cara produksi baru, transportasi baru, pasar-pasar baru, dan manajemen organisasi industrial baru. Barang-barang dagangan selalu harus dibeli dan rakyat dipacu untuk terus menjadi konsumen belaka. Mekanisme-mekanisme baru untuk memperbesar konsumsi terus-menerus diperbaharui, yang lama diganti dan yang baru diciptakan. Kapitalisme akan mati bila tidak ada yang membeli barang dagangan (komoditi) yang mereka hasilkan. Dari hari ke hari, sistem produksi kapitalis terusmenerus menghasilkan barang-barang baru, termasuk untuk menggantikan barang-barang dagangan yang dihasilkan oleh system produksi non-kapitalis.Selera rakyat dibentuk melalui iklan dan gaya hidup konsumtif yang mampu membangkitkan gairah mengidamkan dan membeli barang-barang baru (Rahman, 2015:3337).

Jaringan kapitalisme global ini menyentuh kampung-kampung di Papua. Kehadirannya diangkut oleh pembangunan dan hadirnya perusahaan-perusahaan untuk mengeruk sumber daya alam di tanah mereka. Laksono (2002) menggambarkan bahwa persentuhan masyarakat tempatan dengan dunia global semakin menunjukkan bahwa perubahan bisa terjadi di mana saja. Oleh karena itu, sangat salah kaprah jika masyarakat lokal di kampung-kampung dianggap tak tersentuh oleh perubahan dan masih murni. Jaringan kepentingan global bekerja melampaui batas geografis dan sekat-sekat lainnya.

Jika kita melihat fenomena di kampongkampung Papua, barang-barang produksi yang masuk ke kampung berasal dari luar dan menjadi cermin dari kemajuan. Seluruh citra kemajuan tersebut dibawa oleh perusahaan-perusahaan transnasional yang melakukan operasinya di tanah Papua. Oleh karena itu, perusahaanperusahaan yang hadir dan mengepakkan sayapnya di tanah Papua tidaklah bisa dilihat sebagai berdiri sendiri, namun sebagai bagian dari jaringan system produksi dari jaringan produksi internasional/global yang ekspansif. Investasi global yang menerjang tanah Papua begitu banyak. Salah dua yang terbesar adalah PT Freeport Indonesia di Timika, Provinsi Papua dan BP Indonesia di Teluk Bintuni, Papua Barat. ${ }^{3}$

Dengan demikian, menjadi jelas bahwa penyingkiran ruang-ruang ekologi dari masyarakat di kampung-kampung Papua dilakukan dengan sistematis yang berjejaring luas dengan kuasa investasi global. Jejaring kuasa investasi global inilah yang memiliki jaringan produksi dan

${ }^{3}$ Lebih lengkap tentang sejarah investasi dan konflik sumber daya alam awal di Papua lihat: http://www.downtoearth-indonesia.org/id/story/ eksploitasi-sumber-daya-alam-di-papua-selama-22tahun-dengan-pendekatan-dari-atas-ke-bawah (diakses 21 Januari 2018). 
modal luas. Akibatnya adalah masyarakat lokal berhadapan dengan jejaring kuasa investasi global yang kuat, dan sekaligus memanfaatkan tangan-tangan kekuasaan lokal untuk mendukung usahanya tersebut. Hal ini ditunjukkan dengan berhasil dibujuknya orang-orang berpengaruh di komunitas masyarakat untuk bergabung dan membela perusahaan. Birokrasi pemerintahan dan aparat keamanan menjadi setali tiga uang dengan menjadi pelindung dari perusahaan. Situasi ini seakan tak terbantahkan dan semakin massif dengan hadirnya perusahaan-perusahaan yang menyertakan aparat keamanaan dan pemandu lokal.

Kondisi yang mencemaskan tersebut seolah-olah berlangsung alamiah dan biasa-biasa saja. Perlahan namun pasti, masyarakat di kampung-kampung menghadapi situasi terdesak dan menyulitkan mereka untuk mengembangkan diri dan membuat keputusan untuk masa depan hidupnya. Yang terjadi kemudian adalah keputusasaan terhadap keadaan yang ada. Situasi ini sangatlah mencemaskan dan berakibat kepada penyingkiran manusia-manusia yang berada di kawasan sumber daya alam tersebut. Broek (2002) mengungkapkan terjadi situasi keterpecahan di tengah masyarakat Papua akibat perbedaan cara pandang dalam merespon perubahan. Segala perubahan yang berada di depan mata harus segera disikapi dengan kondisi yang ada. Di sisi lain, ketidaksiapan menanggapi perubahan itulah yang menyebabkan rasa frustasi untuk mengekspresikan identitas budaya dan jati diri serta sebagai "tuan" di atas tanahnya sendiri.

Rentang panjang proses transformasi sosial ini juga menghadirkan perspektif kolonialistik yang menganggap bahwa kehadiran budaya baru akan merubah orang Papua. Giay (1996) melihat ini sebagai cara pandang yang diterapkan oleh negara Indonesia dalam pelaksanaan pembangunan di tanah Papua. Kekayaan pengetahuan lokal dan kebudayaan Papua dianggap tidak ada atau lebih rendah dari kebudayaan baru yang dipaksakan. Perspektif ini melihat bahwa orang Papua tidak punya kebudayaan dan oleh karena itu harus diberikan "adat" dan kebudayaan baru. Perspektif ini sangat kolonialistik yang berniat untuk menguasai tanah jajahan bersama dengan seluruh sumberdaya yang berada di dalamnya.

Negara dan kekuasaannya sebagai perpanjangan tangan dari investasi global seringkali meremehkan atau dalam bahasa James C. Scott
(1995;Lounela dan Zakaria, 2002:7) melakukan penyederhanaan-penyederhanaan dalam mengelola dan menetapkan regulasi (aturan) terhadap tanah dan hutan. Penyederhanaan inilah yang disebut dengan "simplifikasi negara" (state simplifications) dalam memandang heterogenitas kebudayaan dan masyarakat adat sebagai pemilik hak ulayat atas hutan dan tanah. Dengan demikian, kekayaan pengetahuan yang menggambarkan relasi orang Papua dengan lingkungannya tidak tergali dengan dalam. Salah satu kunci penggalian pengetahuan tersebut adalah menggali bahasabahasa ibu yang menggambarkan relasi tersebut.

Oleh karena itu, sangat penting untuk mencermati kebudayaan dan pengetahuan lokal bukan untuk meromantisir dan eksotik, namun untuk melandasi proses perubahan sosial yang terjadi di tengah masyarakat. Kajian akademik telah memberikan peta yang terang benderang tentang pentingya mencermati pengetahuan masyarakat lokal tentang lingkungan sebagai pondasi nilai-nilai kehidupan untuk menghadapi perubahan sosial. Ruang-ruang ekologi tersebut adalah kehidupan sekaligus juga identitas masyarakat lokal. Pengetahuan lokal tersebut bisa menjadi modal sosial untuk berefleksi dan bersikap di tengah perubahan sosial yang mendesak mereka. Tentu ini bukan hal mudah.

Salah satunya adalah seperti yang diungkapkan dalam kajian Yarman dkk (2013) bahwa sangat penting untuk memperhatikan peranan dari pengetahuan lokal tentang tempattempat sakral bagi masyarakat. Dalam perspektif masyarakat adat, tempat keramat yang tidak boleh dimasuki ataupun mengambil hasil dari lokasi tersebut secara bebas dikarenakan masyarakat menghormati dema dan takut terjadi bencana dan ganjaran dari Dema (penjelmaan leluhur berupa tumbuhan dan satwa yang menempati wilayah tertentu yang dipercaya dapat melindungi manusia yang berbentuk totem).

Totem adalah suatu kepercayaan terhadap satwa dan tumbuh-tumbuhan yang dipercaya sebagai leluhur mereka. Totem tersebut merupakan satwa dan tumbuhan asli (endemik) yang ada di wilayah adat mereka. Masyarakat yang ada di kawasan Taman Nasional Wasur dalam kehidupan tradisionalnya, memanfaatkan sumber daya alam sesuai dengan kebutuhannya, baik yang berasal dari dalam totem-nya maupun di luar totem marganya. Pemanfaatan Totem yang 


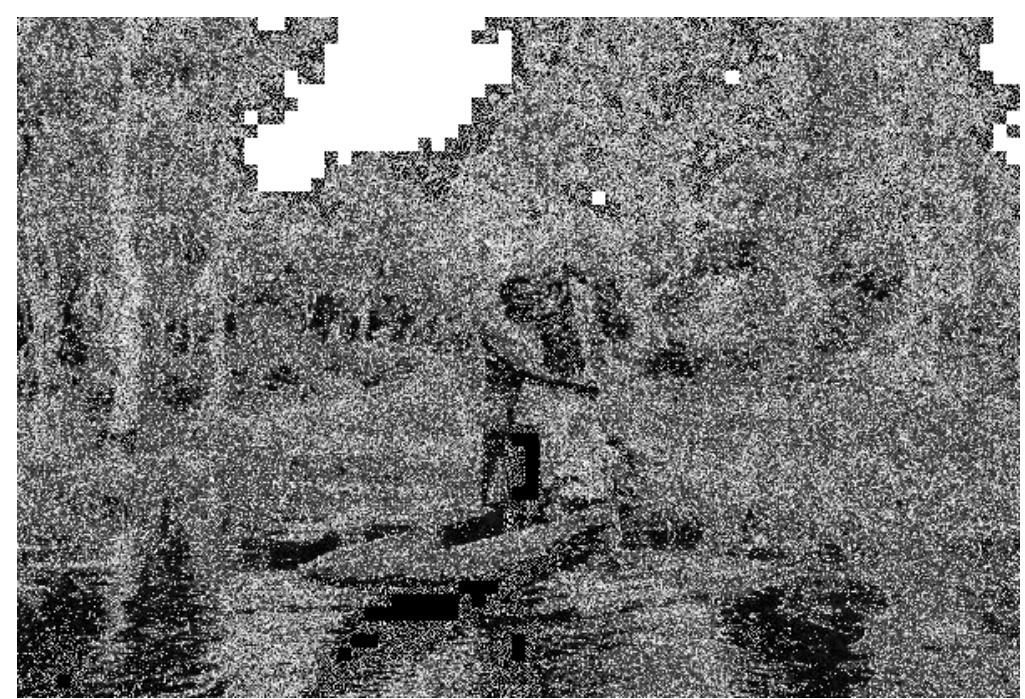

Gambar 3.

Pemanfaatan Sumber Daya Alam yang Secukupnya di Dusun-Dusun adalah Salah Satu Cara Mereka untuk Bertahan di Tengah Arus Perubahan Sosial yang Semakin Deras

(foto: I NgurahSuryawan).

berasal dari luar marga diharuskan meminta izin terlebih dahulu kepada pemilik totem serta memperlakukan totem tersebut sesuai aturan marganya.

Seperti pada pemanfaatan saham (kangguru tanah) yang merupakan Totem dari marga Samkakai. Apabila marga Kaize melakukan perburuan terhadap saham terlebih dahulu meminta izin kepada marga Samkakai. Saham yang telah diburu dengan cara dipanah, kemudian dibelah dari dada sampai ke perut secara vertikal, isi perut dibuang dan kemudian kepala diikat menghadap ke atas. Apabila ada yang melanggar aturan tersebut maka dikenakan sanksi berupa teguran yang dilanjutkan dengan denda tanaman wati, membuat bedeng untuk kebun kumbili (jenis umbi-umbian), dan penyerahan hasil kebun berupa ubi, pisang, dan apabila masih melakukan pelanggaran akan dihukum mati(Yarmandkk, 2013: 112-113). Pengetahuan lokal tersebut lahir, tumbuh dan terjaga di lingkungan masyarakat lokal berelasi dengan kepercayaan (religi) yang tak terpisahkan. Dalam konteks etnoekologi, pengetahuanpengetahuan lokal inilah yang sebenarnya harus diperhatikan sebagai jalan tengah dalam usaha pemanfaatan kekayaan sumber daya alam yang arif dan berpihak kepada kelangsunganhidup masyarakat lokal yang berkelanjutan.

\section{Bahasa-Bahasa Lokal dan Ekologi}

Jika mengamati keseluruhan proses kebudayaan yang menyertai relasi manusia dengan lingkungan alamnya, sebenarnya terdapat kekayaan yang luar biasa di dalamnya. Kekayaan tersebut terdapat dalam nilai-nilai dan pengetahuan yang dihasilkan dari proses hubungan tersebut. Perspektif (cara pandang) masyarakat dan bagaimana masyarakat membangun pengetahuan dari lingkungan alam itulah yang menjadi pondasi dari semuanya. Totalitas kebudayaan itulah yang menghasilkan pengetahuan ekologi yang menjadi dasar dari kehidupan mereka. Keseluruhannya itu diekspresikan melalui kesenian, ritus-ritus, dan salah satunya adalah bahasa yang menjadi penanda kebudayaan itu sendiri.

Bahasa lokal memberikan penamaan terhadap ruang-ruang ekologi tersebut bukannya hampa makna. Keseluruhan proses tersebut lahir dari proses relasi panjang sejarah manusia dan lingkungannya. Proses tersebut melekat dalam berbagai macam nilai-nilai yang hidup di tengahtengah masyarakat dan menjadi pandangan hidup bersama. Nilai-nilai tersebut misalnya yang berhubungan dengan kepercayaan tentang tempat sakral dan "dusun-dusun" yang dipercaya sebagai tempat bersemayamnya nenek moyang dan para leluhur yang melindungi mereka dalam kehidupan. Berbagai jenis kepercayaan dan pengetahuan lokal tentang hal ini lahir dan berkembang di berbagai komunitas masyarakat di tanah Papua, tak terkecuali pada masyarakat 
Marori dan Kanum di Kabupaten Merauke. Masing-masing marga orang Marori dan Kanum mempunyai peta tentang zona-zona/ruang-ruang ekologi masing-masing yang berhubungan dengan relasi mereka dengan lingkungan dan kepercayaan lokal lainnya.

Khusus untuk orang Kanum, beberapa wilayah-wilayah yang dimiliki oleh masingmasing marga termasuk ke dalam wilayah Taman Nasional Wasur. Di kawasan Taman Nasional Wasur (TNW) tersebut, wilayah masing-masing marga sebenarnya terdapat wilayah-wilayah yang telah diatur melalui adat dan kesepakatan masing-masing marga. Masingmasing marga sebenarnya memiliki peta pengetahuan tentang wilayah-wilayah sakral dan pemanfaatan untuk sumber daya alam yang ada. Marga Maiwa yang merupakan salah satu marga orang Kanum memiliki peta pengetahuan mengenai ruang-ruang hidup mereka dengan bahasa lokal. Keseluruhannya menggambarkan pengetahuan mereka dalam pengelolaan sumber daya alam.

Marga Maiwa membagi wilayah-wilayah hidup mereka dalam beberapa zona yaitu pertama, wilayah inti di mana orang Kanum percaya bahwa di tempat inilah para leluhur tinggal dan melindungi mereka di kampungkampung. Wilayah inti ini mereka sebut dengan Kalbala yang juga merupakan zona sakral yang dipercayai mempunyai nilai-nilai sejarah terhadap kehidupan mereka hingga seperti sekarang ini. Tempat-tempat sacral ini meliputi jejak perjalanan leluhur dan daerah-daerah yang berperanan penting dalam menopang kehidupan mereka.

Zona kedua yang disebut Yamai yaitu wilayah pemanfaatan. Pada zona ini masyarakat mempergunakan untuk membuat kebun sesuai dengan wilayahnya masing-masing. Orang Kanum akan menggunakan wilayah Yamai ini sebagai sumber kehidupan mereka yaitu untuk membuat kebun guna menghasilkan bahan makanan untuk kehidupan mereka sehari-hari. Orang Kanum biasanya akan menanam pisang, ubi, keladi, dan tanaman yang berguna untuk mencukupi kebutuhan hidup mereka. Mereka juga akan menanam kelapa, sagu, sayur-sayuran di kebun. Wilayah Yamai adalah wilayah kehidupan mereka.

Orang Kanum biasanya akan membuat bivak-bivak di wilayah Yamai ini. Mereka bisa berminggu-minggu di dong pu kebun (di kebun mereka) untuk memastikan kebutuhan sehari-hari tersedia dan kemudian dibawa ke kampung. Bivak-bivak tersebut dibuat dengan sederhana hanya untuk tempat istirahat mereka sementara waktu selama berada di dusun. Dusun adalah istilah yang sering meraka gunakan merujuk kebun-kebun sebagai sumber penghidupan mereka.

Zona ketiga adalah yang disebut dengan $\mathrm{Kel}$ yaitu kampung yang merupakan tempat pemukiman. Lokasi pemukiman penduduk ini adalah wilayah yang sering digunakan sebagai aktivitas kehidupan mereka sehari-hari. Aktivitas orang Kanum, seperti juga orang Papua kebanyakan, akan menjadikan wilayah pemukiman ini tempat utama aktivitas selain dusun-dusun tempat mereka mencari makanan.

Yunus Maiwa menjelaskan bahwa saat ini wilayah-wilayah zona inti yang merupakan zona leluhur dan sakral sudah sangat jauh berubah menuju kondisi yang sangat memprihatinkan. "Wilayah Kalbala itu sakral dan dilindungi. Di sanalah Taori (kangguru) hidup. Ia mendapatkan perlindungan di wilayah leluhur. Tapi itu dulu," kisahnya. Di wilayah Kalbala ini diindungi sekaligus dilestarikan seluruh tanaman dan binatang di dalamnya. Masyarakat akan berjaga dan mengetahui siapa saja yang masuk ke wilayah Yamai dan Kalbala. Mayoritas adalah para pemburu dan juga orang-orang luar yang datang ke wilayah orang Kanum untuk mencari penghidupan dengan cara berburu dan mengambil hasil bumi yang ada di wilayah mereka.

Yunus Maiwa menuturkan bahwa binatangbinatang yang dulu bisa muncul di wilayahwilayah pemukiman mereka di kampung-kampung, kini sudah tidak ada lagi. "Binatang-bintang yang ada di zona inti orang-orang dong dikejar terus sehingga zona inti ini rusak, hancur," jelasnya. Yunus Maiwa menyesalkan hal ini terjadi tapi tidak bisa berbuat banyak karena hal ini menyangkut soal perut, persoalan kebutuhan yang tidak bisa ditawar-tawar lagi.

Orang-orang luar datang untuk berburu dan mengambil keuntungan dari alam orang Kanum. Mereka - orang-orang luar - ini datang dengan menggandeng orang-orang Kanum sendiri yang dimanfaatkan sebagai alat masuk untuk berburu dan mengambil hasil alam orang Kanum (menangkap ikan, mengambil kayu dan yang lainnya). Secara tidak langsung orangorang Kanum sendiri juga berkontribusi pada kerusakan alamnya sendiri. "Sudah hancur. Contohnya rusa dicari terus sampai ke dalam- 
dalam sehingga buat binatang ini tidak tenang," kisahnya. Jika dahulu, rusa-rusa ini bisa sampai mencari makanan hingga ke kampung-kampung sehingga sering dilihat oleh masyarakat. Tapi kini tidak terjadi. Rusa-rusa hanya tinggal di dalam karena terus-menerus diburu sehingga tidak akan muncul di perkampungan masyarakat.

Keprihatinan yang sama juga terjadi di wilayah orang Marori. Orang Marori menghadapi ancaman yang serius terhadap kelangsungan tempat-tempat sakral penyangga hidup mereka, terutama daerah-daerah dusun-dusun sagu di kawasan hutan sekitar kampung. Warga Kampung Wasur memang masih percaya bahwa daerah-daerah yang ke dalam hutan masih belum terjamah oleh para tukang sensor, tapi bukan tidak mungkin akan habis ditebang. Tempattempat pamali dan sakral bagi Suku Marori Mengey memang berada tersebar di bagian pinggir dan dalam hutan mereka. Tempat khusus untuk bagian pinggir hutan biasanya ada tempattempat keramat yang biasanya ditandai dengan pohon beringin tua atau sumur-sumur sebagai mata air. Di tempat-tempat itulah biasanya marga pemilik tempat pamali tersebut menghaturkan sirih pinang, lempeng dan rokok kepada leluhurleluhur mereka yang masih tinggal di lokasi tersebut. Dominikus Kaize masih mengingat di Mesei, yaitu lokasi keramat dari marga Kaize yang berupa sungai kecil dan rawa sagu terdapat pohon beringin tua yang diyakini sebagai warisan dari nenek moyang. Di pohon beringin tua itulah biasanya marga Kaize menempatkan siring pinang, lempeng dan juga rokok sebelum mengambil sesuatu di Mesei.

Berdekatan dengan Mesei adalah Kali Dualol yang juga merupakan tempat keramat bagi marga Kaize. Dominikus Kaize mengisahkan pernah pada suatu hari para pemburu dari kota yang belum meminta izin kepada moyang di Mesei berburu di sekitar kali Dualol yang terkenal dengan kali yang dalam. Para pemburu dari kota ini membawa anjing untuk berburu. Tanpa diduga sebelumnya tiba-tiba ada burung Kasuari melintang di tengah jalan saat pemburu mulai memasuki kali Dualol. Semua pemburu tersebut heran dan meyakini ada sesuatu yang aneh terjadi. Dari kejadian itu, Dominikus Kaize meyakini bahwa di tempat-tempat sakral tersebut masih diawasi oleh para leluhur. Oleh warga kampung, terhadap kejadian aneh-aneh tersebut sering menyebutnya sebagai Kudung yaitu mahluk yang menyerupai manusia dengan tangan dan kaki terputus dan badan terbakar. Domikus
Kaize meyakini bahwa melihat Kudung berarti menandakan bahwa para leluhur Marori Mengey itu sudah cacat dan sedih melihat hutan tempat mereka tinggal sudah dirusak oleh keturunanya sendiri.

Bahasa-bahasa lokal yang menjadi cerminan dari relasi manusia dengan ekologinya juga terdapat dalam praktek ekologi bernama Sasi. Bahasa Kanum menyebutnya dengan Sar. Nataniel Ndimar mengisahkan bahwa untuk menjaga lingkungan alam dari kepunahan mereka menerapkan konsep Sar yang bisa disamakan dengan pelaksanaan Sasi adat untuk melestarikan sumber daya alam yang berada di sekitar lingkungan alam mereka. Wilayahwilayah yang menerapkan Sar akan menjaga lingkungannya dari pemanfaatan yang mereka lakukan selama ini. Wilayah-wilayah Sar inilah yang tidak bisa diganggu gugat untuk pemanfaatannya. Masyarakat Kanum biasanya akan melakukan Sar di wilayah-wilayah yang menjadi sumber penghidupan mereka sehari-hari. Sar dilakukan saat masyarakat merasa bahwa sumber daya alam yang menjadi sumber penghidupan mereka di dusun-dusun rawa, kayu, dan sagu mulai terasa habis atau masyarakat melihat ada orang-orang luar yang mencuri kayu dan sumber daya lain dari kampung mereka.

Pelaksanaan Sar tidak dapat diganggu gugat oleh siapapun jika sudah diputuskan untuk dilakukan. Sar sengaja dilakukan untuk melindungi lingkungan alam yang merupakan wilayah ulayat masing-masing marga. Warga Kampung Tomerauw mempunyai kepercayaan bahwa dalam pelaksanaan Sar nanti setidaknya akan ditemukan beberapa orang yang menyalahi aturan dengan merusak lingkungan alam mereka. Oleh karena itu, Sar sengaja dilakukan untuk memberikan hukuman kepada orang-orang yang secara sengaja merusak alam, selain tentu saja untuk menjaga kelestarian alam. Pelaksanaan Sar atau sasi adat itu ditandai dengan pemasangan Mengga, daun kelapa di Tanam Misar, yaitu nama kayu dari Tomerauw yang biasanya digunakan untuk tanda Sar. Setelah itu, Mengga dan Tanam Misar ini kemudian diikat dengan tali dari pohon kelapa. Jika menemukan tanda-tanda seperti itu di lokasi dusun sagu, kayu ataupun rawa dan sungai, bisa dipastikan bahwa di lokasi tersebut sedang diberlakukan sasi adat. Jadi jangan mengharapkan untuk mencari sesuatu di lokasi tersebut. Masyarakat Tomerauw mempercayai jika bersikeras untuk mencari 
sesuatu di lokasi pemberlakuan sasi adat, maka bahaya akan siap mengancam cepat atau lambat.

Pelaksanaan sasi adat berlangsung lebih kurang dua hingga tiga tahun untuk kemudian dibuka kembali bagi masyarakat memanfaatkan sumber daya alam di lingkungan tersebut. Pembukaan sasi adat dilakukan dengan acara adat juga. Acara adat yang dilakukan adalah dengan membunuh babi, menokok sagu, melengkapinya dengan udang yang mereka dapatkan di sungai dan rawa untuk kemudian dibagikan kepada kerabat yang ada di kampung. Tanda sasi adat yang biasanya dilakukan di dusun-dusun sagu dan kayu ini kemudian dilepas. Saat dilepasnya Sar adat pelaksanaan dilakukan di dusun-dusun sagu dengan mengundang sanak family di kampung untuk menyaksikannya. Marga yang melakukan pembukaan Sar akan mengundang jaringan kekerabatannya untuk melihat langsung dan membagikan berbagai makanan di lokasi dusun sagu. Beberapa diantara makanan itu adalah hasil dari olahan sagu yang mereka sebut dengan $\operatorname{Sef}$, yaitu makanan dari sagu yang diolah menyerupai makanan seperti nasi untuk dibagikan pada pelaksanaan acara adat.

Salah satu Sasi yang juga sering dilakukan oleh masyarakat Tomerauw adalah Sasi rawa yaitu usaha untuk menjaga berkembangbiaknya ikan-ikan yang berada di wilayah Suku Kanum di Tomerauw. Sasi rawa ini biasanya dilakukan jika sudah melihat hasil tangkapan ikan penduduk di kampung sudah mulai menurun. Saat saya datang pada bulan April 2016 ke Tomerauw, masyarakat kampung sedang bergembira karena inilah bulan musim panen ikan yang ada di rawa-rawa di sekitar kampung. Ini juga berarti adalah rezeki besar bagi warga kampung. Mereka telah puasa untuk musim ikan selama dua tahun lamanya pada saat Sar. Setelah Sar dibuka berarti ikan-ikan sudah berkembang biak dengan baik dan saatnya untuk ditangkap. Saya menyaksikan tidak ada pembukaan Sar (sasi adat) yang saya saksikan sore itu di Kampung Tomerauw. Memang saya hanya beberapa jam saja di Tomerauw sebelum kembali lagi ke Wasur.

Nataniel Ndimar mengungkapkan bahwa jika musim ikan di rawa tiba, maka bisa dipastikan "orang-orang kota", begitu mereka menyebutnya akan datang menuju Tomerauw dengan menyiapkan puluhan cool box (tempat pendingin ikan). Para "orang-orang kota" ini akan rela untuk menunggu di kampung berjamjam guna mendapatkan ikan dari para warga. Nataniel Ndimar mengungkapkan bahwa ikanikan yang mereka dapatkan dalam jumlah banyak karena pemberlakuan Sar (Sasi). Masyarakat di Kampung Tomerauw sangat menghormati pelaksanaan Sar ini, termasuk juga orang-orang dari luar kampung yang masih memahami arti penting dari pelaksanaan Sar rawa ini. Namun tidak demikian dengan "orang-orang kota" ini. Mereka dengan gampang saja datang ke kampung untuk mendapatkan hasil dari masyarakat kampung yaitu ikan rawa. Masyarakat kampung mendapatkan uang dan begitu seterusnya.

Nataniel Ndimar pada sore itu mengungkapkan bahwa masyarakat di kampong belum berpikir untuk mengelola hasil ikan mereka secara mandiri. Yang ada dalam pikiran mereka adalah menjual dan mendapatkan uang dengan sesegera mungkin. Hingga kini masyarakat di Kampung Tomerauw belum pernah untuk mengelola hasil bumi sendiri. Oleh karena itulah orang-orang luar selalu melihat peluang kekayaan sumber daya alam yang dimiliki oleh Kampung Tomerauw. Sehingga yang terjadi adalah orang-orang luar selalu mencuri hasil alam, termasuk yang ada di rawarawa yang sangat kaya. Ndimar mencontohkan sumber daya yang terdapat di rawa-rawa yang berada di belakang kampung. Setelah memberlakukan Sar, yaitu larangan bagi semua orang untuk mencari ikan, udang, dan berburu buaya, mahluk hidup yang berada di rawa mempunyai perkembangan yang baik. Oleh karena itu, setelah Sar dibuka, bisa dipastikan bahwa hasil yang akan didapatkan akan lebih banyak.

Selain Sar bagi marga Ndimar, praktik ekologi untuk perlindungan sumber daya alam lainnya bagi orang Kanum adalah wilayah tempat-tempat sakral sagu yang sangat mereka jaga sangatlah berperanan penting sebagai sumber penghidupan mereka sehari-hari. Tempattempat tumbuhnya sagu di dalam rawa-rawa yang terbentang luas di belakang perkampungan selalu mereka jaga dan rawat. Yang merusak rawa sagu berarti juga bunuh diri untuk kehidupan mereka selanjutnya. 


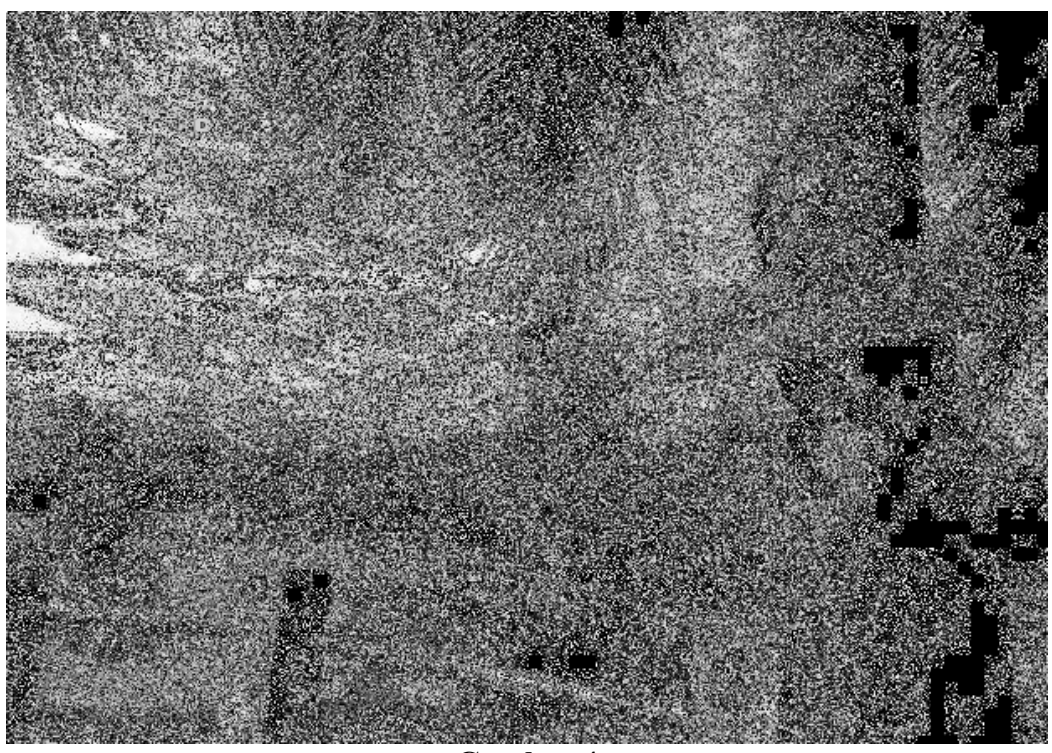

\section{Gambar 4}

Cara memperlakukan alam adalah satu kesatuan totalitas kebudayaan yang dimiliki masyarakat lokal sebagai bentuk penghargaan mereka terhadap leluhur

(foto: I Ngurah Suryawan).

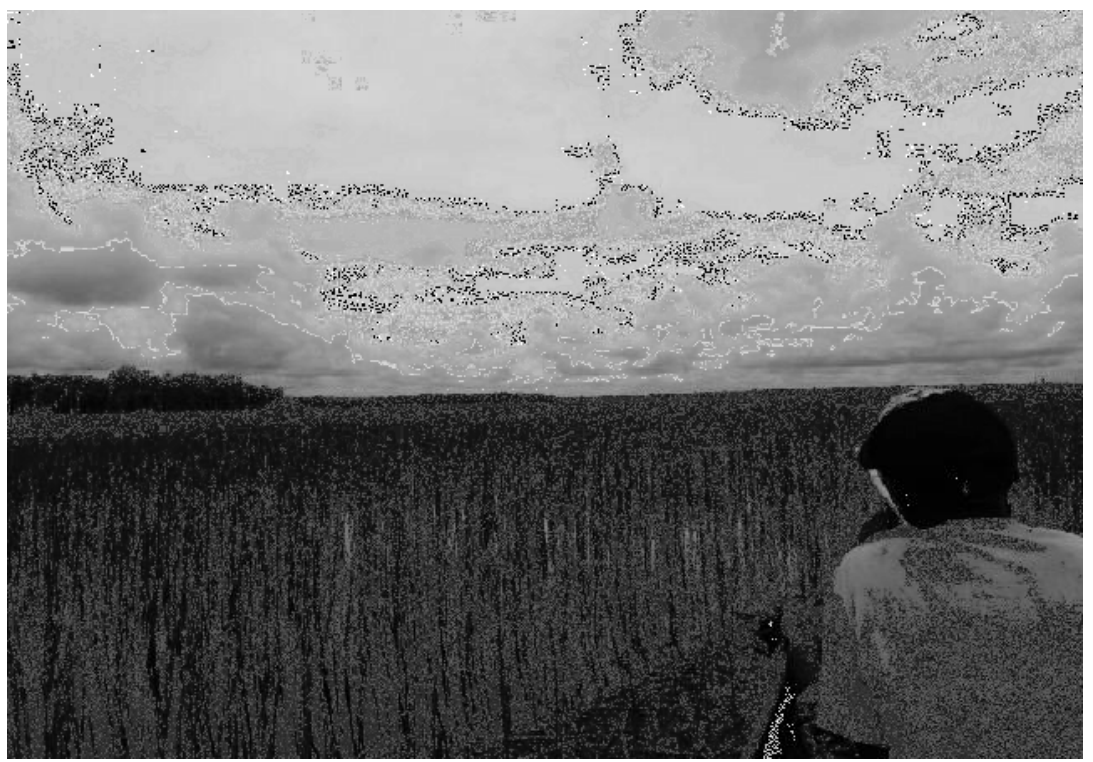

Gambar 5

Ruang-ruang ekologi yang luas memberikan pelajaran yang sangat berharga bagi masyarakat lokal untuk membentuk identitas dirinya dan menciptakan pengetahuan yang kaya (foto: I Ngurah Suryawan).

Pohon-pohon sagu yang tumbuh di wilayah rawa-rawa di Kampung Rawa Biru bagi orang Kanum Smerkey sangat mereka sakralkan. Wilayah rawa sagu tersebut diberi nama Ntemtom. Di wilayah ini akan terus-menerus tumbuh sagu tanpa ada habis-habisnya, sehingga mereka percaya bahwa sagu di lokasi ini adalah sakral. Mereka juga mempercayai bahwa sagu di Rawa Biru menjadi cikal bakal penyebaran sagu oleh nenek moyang mereka di kampungkampung orang Kanum lainnya.

Jika sagu mereka yakini akan terus tumbuh karena para leluhur selalu menjaga dan lingkungan selalu menghidupinya, tidak demikian dengan yang lainnya. Sumber daya alam yang mengelilingi rawa-rawa sagu di wilayah orang Kanum sangat rentan untuk habis tereksploitasi oleh orang luar maupun orang Kanum sendiri 
hanya demi mencari uang. Eksploitasi yang berlebihan itulah yang dikhawatirkan akan merusak keseimbangan lingkungan alam Kanum.

Sasi bagi orang Kanum bertujuan untuk menghemat sumber daya alam yang ada di wilayah mereka. Secara khusus di Kampung Tomerauw, Sasi dilakukan jika mereka memandang sudah tidak terjadi keseimbangan tempat di mana binatang maupun tumbuhan tersebut hidup berkembang. Orang Kanum memiliki pandangan bahwa jika ada ketidakseimbangan dalam rantai makanan akan dengan mudah terlihat dengan liarnya binatang untuk mencari makanan di sekitar wilayah kampung. Jika ini sampai terlihat, maka bisa dipastikan bahwa telah terjadi permasalahan dalam keseimbangan lingkungan hidup.

Yunus Maiwa mencontohkan bahwa yang menjadi perhatian sebelum pelaksanaan Sasi adalah memperhatikan mahluk hidup yang berada di kawasan air dan darat. Kawasan air yang terutama adalah ikan. Kawasan darat ini yang beragam masing-masing marga. Tapi yang terutama adalah babi, rusa, dan kangguru. Jika binatang-binatang ini menjadi liar, maka ada yang salah dalam keseimbangan lingkungan, terutama yang berhubungan dengan rantai makanan dengan manusia. Hal ini berarti manusia telah berbuat salah dan merusak ketenangan ekosistem yang ada. Dengan situasi seperti itu, maka sangat diperlukan untuk melakukan Sasi untuk memastikan keberlangsungan hidup ekosistem tetap berjalan baik.

Sasi dilakukan untuk melarang pembunuhan hewan atau perusakan lingkungan dan memberikan kesempatan kepada mahluk hidup tersebut untuk berkembang biak. Oleh karena itu, dilakukan Sasi selama dua bulan dengan berpindah-pindah ke berbagai lokasi yang dianggap sangat perlu untuk dilakukan. Pelaksanaan Sasi dilakukan berpindah-pindah untuk menandai lokasi Sasi. Batas pelaksanaan Sasi sangat beragam sesuai dengan perhitungan dapat berkembang biaknya mahluk hidup secara seimbang kembali.

Selama pelaksanaan Sasi, orang Kanum berpandangan bahwa pada masa itulah masa tenang bagi mahluk hidup untuk berkembang biak dengan tenang. Yunus Maiwa mengungkapkan bahwa Sasi memberikan kesempatan kepada hewan-hewan untuk makan tenang dan berkembang biak tanpa diteror untuk perburuan yang dilakukan oleh manusia. Jika pelaksanaan Sasi berlangsung, dan manusia tidak melakukan perburuan, maka bisa dipastikan hewan-hewan khususnya akan tenang makan dan berkembang biak. Ini memastikan bahwa keseimbangan sumber daya akan terjaga dan juga menguntungkan manusia.

Perburuan yang liar dan tidak terkendali adalah alasan kuat lainnya untuk melaksanakan Sasi. Situasi perburuan liar ini sangat memprihatinkan bagi orang Kanum sehingga diperlukan langkah cepat untuk melakukan Sasi. Yunus Maiwa mengungkapkan bahwa perburuan hewan (kangguru, rusa, buaya, dan babi) dan ikan sudah menguasai semua tempat yang berada di wilayah orang Kanum. Masyarakat bukannya diam. Mereka sudah berusaha untuk mencari pemburu-pemburu tersebut, namunnya mencarinya setengah mati. Tetap saja berlangsung tanpa henti perburuan tersebut sehingga mengancam keberadaan dari hewan-hewan yang berada di wilayah orang Kanum.

Orang Kanum melakukan ritual Sasi dengan memberi tanda di suatu tempat. Tandanya berupa potongan tiang dari kayu yang tahan lama. Biasanya digunakan kayu besi karena akan tahan bertahun-tahun. Ini dilakukan karena pelaksanaan Sasi bisa berlangsung lebih dari satu tahun sesuai dengan kebutuhan dan keputusan dari masing-masing marga pemilik hak ulayat tempat berlangsungnya Sasi. Potongan kayu tersebut kemudian diikat dengan alang-alang dan daun kelapa. Potongan kayu panjang tersebut kemudian ditancapkan di wilayah-wilayah yang diberlakukan Sasi. Ada juga yang dipasang di pohon kelapa ciri dari Sasi tersebut sesuai dengan kondisi wilayah yang akan disasi. Jika tanda tersebut sudah terpasang, bisa dipastikan bahwa tempat tersebut sedang disasi menurut adat dari orang Kanum.

Proses pemberlakuan Sasi bisa berlangsung berbulan-bulan dan juga bertahun-tahun. Semuanya disepakati oleh marga-marga tentang batas waktu pelaksanaan Sasi. Yunus Maiwa menjelaskan, marga Maiwa pernah melakukan Sasi di kepala sungai di Rawa Biru. Pada saat itu Sasi dilakukan karena maraknya perburuan buaya yang berlangsung di kawasan Rawa Biru yang merupakan salah satu wilayah orang Kanum. Saat itu, terutam di kepala kali Rawa Biru, peruburuan buaya merambah hingga wilayahwilayah sakral yang dilindungi oleh orang Kanum.

Oleh karena itu, pemilik wilayah berkembang biaknya buaya di kepala kali Rawa 
Biru itu yaitu Kanum Smarkey, Barkari, dan Ngelembu menyepakati untuk menutup wilayah tersebut dari perburuan buaya. Mereka sangat khawatir dengan terancamnya keberadaan buaya di wilayah Rawa Biru karena terus-menerus diburu. Sasi terhadap buaya ini diberlakukan selama tujuh tahun sehingga memberikan waktu untuk buaya berkembang biak. Masyarakat sekitar hanya boleh mencari ikan dan binatang saja di sekitar wilayah Rawa Biru.

Tidak hanya buaya saja yang menjadi perhatian masyarakat Kanum. Salah satu binatang yang selalu menjadi incaran para pemburu lainnya adalah rusa. Perburuan rusa sempat mengkhwatiran masyarakat saat banjir pemburu dari dari luar. Maka dari itu diberlakukan Sasi rusa selama enam bulan dan baru kemudian membukanya lagi pada saat musim kemarau. Masyarakat Kanum menilai bahwa keberadaan rusa mengalami keterancaman setelah tidak ada lagi rusa yang mencari makan di sekitar kampong mereka, Kampung Toemrauw khususnya. Ini jelas sesuatu yang aneh. Sebelumnya rusa-rusa tersebut mencari makan di sekitar kampung mereka, bahkan menonton kita makan. Namun keadaan tersebut berubah sangat cepat. Rusa-rusa sekarang tidak lagi mencari makan di dekat-dekat kampung karena sudah diburu hingga ke pedalaman. Situasi ini jelas sangat memprihatinkan.

\section{Siasat di Tengah Perubahan}

Perubahan sosial yang tejadi bagi orang Marori dan Kanum berdampak sangat besar bagi kelangsungan hidup mereka. Salah satu dampak besar tersebut adalah yang berhubungan dengan pemanfaatan sumber daya alam di wilayah ekologi mereka, yang juga termasuk dalam kawasan wilayah konservasi Taman Nasional Wasur. Orang Marori dan Kanum adalah dua suku yang termasuk berada di kawasan konservasi tersebut. Di tengah-tengah kawasan konservasi tersebut, mereka harus berjuang untuk bertahan hidup di tengah berbagai macam aturan tentang wilayah konservasi yang harus mereka taati.

Wilayah-wilayah tersebut bukannya tanpa tuan. Sebelumnya mereka - masyarakat lokal orang Marori dan Kanum - adalah pemilik wilayah tersebut. Mereka mempunyai sejarah panjang terhadap kepemilikan kawasan ekologi dan lahan-lahan yang menjadi sumber penghidupan. Ruang-ruang ekologi tersebut adalah kehidupan mereka. Relasi manusia dengan ruang-ruang ekologi itulah yang menciptakan begitu banyak pengetahuan lokal berbasis kepada kepercayaan mereka terhadap nenek moyang yang mewariskan tanah kepada mereka. Kondisi inilah yang yang menjadi pondasi cara mereka berelasi dengan lingkungan sekitarnya. Namun, situasi kini sudah berubah perlahan-lahan, pelan tapi pasti menuju hilangnya ruang-ruang ekologi tersebut. Kawasan konservasi dan pemanfaatan yang berlebihan terhadap sumber daya alam yang mereka miliki menjadi salah satu sebabnya. Pelakunya selain juga dari orang di luar kampung, juga saudara mereka sendiri yang bersedia menjadi kaki tangan dari orang-orang luar yang mengeruk kekayaan alam mereka.

Perubahan sosial yang tejadi bagi orang Marori dan Kanum berdampak sangat besar bagi kelangsungan hidup mereka. Salah satu dampak besar tersebut adalah yang berhubungan dengan pemanfaatan sumber daya alam di wilayah ekologi mereka, yang juga termasuk dalam kawasan wilayah konservasi Taman Nasional Wasur. Orang Marori dan Kanum adalah dua suku yang termasuk berada di kawasan konservasi tersebut. Di tengah-tengah kawasan konservasi tersebut, mereka harus berjuang untuk bertahan hidup di tengah berbagai macam aturan tentang wilayah konservasi yang harus mereka taati.

Wilayah-wilayah tersebut bukannya tanpa tuan. Sebelumnya mereka - masyarakat lokal orang Marori dan Kanum - adalah pemilik wilayah tersebut. Mereka mempunyai sejarah panjang terhadap kepemilikan kawasan ekologi dan lahan-lahan yang menjadi sumber penghidupan. Ruang-ruang ekologi tersebut adalah kehidupan mereka. Relasi manusia dengan ruang-ruang ekologi itulah yang menciptakan begitu banyak pengetahuan lokal berbasis kepada kepercayaan mereka terhadap nenek moyang yang mewariskan tanah kepada mereka. Kondisi inilah yang yang menjadi pondasi cara mereka berelasi dengan lingkungan sekitarnya. Namun, situasi kini sudah berubah perlahan-lahan, pelan tapi pasti menuju hilangnya ruang-ruang ekologi tersebut. Kawasan konservasi dan pemanfaatan yang berlebihan terhadap sumber daya alam yang mereka miliki menjadi salah satu sebabnya. Pelakunya selain juga dari orang di luar kampung, juga saudara mereka sendiri yang bersedia menjadi kaki tangan dari 
orang-orang luar yang mengeruk kekayaan alam mereka.

Ruang-ruang ekologi tersebut seperti dijelaskan sebelumnya menjadi berkurang karena alasan konservasi. Di sisi lainnya, masyarakat lokal memiliki kepentingan untuk memanfaatkan sumber daya alam yang berada di wilayah mereka. Tarik-menarik kepentingan inilah yang pada tataran teknis terjadi di lapangan. Pada tataran konseptual meski dipikirkan benturan pemikiran tentang konservasi modern dengan ide pengelolaan sumber daya alam bagi masyarakat lokal. Muara dari semua itu adalah kepentingan politik ekonomi dalam pengelolaan sumber daya alam. Masyarakat lokal, meski bagaimanapun, akan terus bertahan di tengah perubahan yang terjadi. Perjuangan untuk bertahan itulah yang kemudian menimbulkan permasalahan.

Orang Marori dan Kanum di tengahtengah keterhimpitan ruang-ruang ekologi tersebut, mereka mencoba berjuang untuk bertahan hidup dengan berbagai cara. Tidak jarang cara-cara tersebut justru merusak lingkungan sekitarnya karena dianggap tidak melakukan upaya konservasi. Tuduhan-tuduhan semacam itu datang dari lembaga-lembaga yang bernaung di bawah ideologi konservasi atau bahkan dari kalangan taman nasional dengan berbagai aturan-aturan yang mereka terapkan. Masyarakat lokal akhirnya menjadi pihak yang disalahkan karena dianggap tidak pro-konservasi.

Salah satu kegiatan yang selalu mendapatkan kecaman namun masih terus berlangsung tanpa henti adalah sensor (pemotongan) kayu di kawasan Taman Nasional Wasur. Sensor kayu adalah aktivitas laki-laki tua maupun muda untuk "berburu" kayu-kayu di tengah hutan dan kemudian dijual kepada penadah kayu yang berasal dari kota Merauke yang rela datang atau memasang "orang-orangnya" di Kampung Wasur. Mereka, para penadah kayu ini biasanya berani untuk memberikan uang di muka kepada warga kampung untuk mendapatkan kayu langsung dari warga. Karena tuntutan "perut" (ekonomi), maka masyarakat dengan berbagai cara mencari kayu di hutan-hutan di sekitar kampung. "Sетиa baku balomba," ungkap Lukas Ndiken, salah satu tetua orang Marori di Kampung Wasur. Anak-anak muda yang akan menebang kayu, jika ditanya oleh warga akan menjawab, "Mau masuk ke rumah teteh." Ungkapan tersebut berarti bahwa akan pergi ke hutan untuk mensensor kayu.
Lukas Ndiken melihat perilaku "pencuri kayu" dari warga kampung melewati batas-batas wilayah marga mereka. Orang-orang lain yang tidak memiliki hak atas wilayah tersebut juga masuk dan juga dari orang luar yang menadah kayu atau memakai kaki tangannya yang warga di kampung untuk mencari kayu. Sebenarnya menurut Lukas Ndiken masing-masing marga sudah mempunyai dusun-dusun sendiri untuk mencari penghidupan, bukan hanya mensensor kayu tetapi juga mencari sayur-sayuran, menokok sagu dan juga berburu. Tapi yang terjadi sekarang justru sebaliknya, semuanya berburu uang untuk keperluan makan dengan menjual kepada para penadah kayu dari kota. Bahkan Lukas Ndiken mengungkapkan para penadah kayu dari kota bisa memberikan uang lebih awal kepada keluarga-keluarga di kampung agar nanti hasil sensornya diberikan kepadanya.

Kayu-kayu yang berada di hutan-hutan marga Suku Marori Mengey dan masuk ke wilayah Taman Nasional Wasur jika terus disensor akan cepat habis. Lukas Ndiken mengkhwatirkan habisnya kayu di hutan-hutan Wasur sehingga tidak ada lagi sumber penghasilan para warga kampung. Jika pada musim panas yang ada di kampung adalah perempuan-perempuan saja. Para lelakinya akan mencari kayu ke hutanhutan. Hanya dengan mencari kayu uang akan cepat didapat dibandingkan pekerjaan lainnya seperti berkebun atau mencari ikan. Sebagian besar para lelaki di Kampung Wasur menggantungkan hidupnya untuk mencari kayu dan menjualnya kepada penadah kayu. Pekerjaan berkebun bisa dihitung dengan jari yang dilakukan oleh Suku Marori Mengey. Pekerjaan berkebun biasanya dilakukan oleh para pendatang dari NTT dan Maluku atau suku lainnya.

Lukas Ndiken menuturkan jika harapan hanya mensensor kayu itu berarti tidak ada apaapa bagi orang Marori Men Gey. Jika pada tahun 2030 kayu sudah habis, harapan hanya kayu bakar untuk dijadikan uang yang semakin lama semakin menipis. Harapan lain tidak ada. Suku Marori Mengey sebenarnya mempunyai tanah luas tetapi tidak mampu untuk mengolah tanah tersebut menjadi makanan dan uang untuk menyambung hidup. Yang dilakukan selama ini adalah memanfaatkan hasil alam yang ada tanpa mampu mengolahnya.

Orang Marori sebenarnya telah diingatkan melalui cerita-cerita para tetuanya bahwa leluhur 
mereka murka dan tidak senang dengan lingkungan yang sudah rusak. Ruang-ruang ekologi yang sebelumnya adalah tempat sacral dan menjadi "rumah" bagi para moyang, kini telah rusah karena sensor kayu begitu memprihatinkan. Dominikus Kaize mengungkapkan kisah menyeramkan itu sebagai pengalaman yang tidak akan pernah dia lupakan. Hal yang lebih penting lagi adalah bahwa pengalaman itu adalah teguran bagi orang-orang Marori untuk menghentikan perusakan lingkungan hingga ke tempat-tempat sakral dan pamali.

Kisah menyeramkan tersebut terjadi pada saat Dominikus Kaize berada di daerah sakral milik dari marga Kaize. Ceritanya begini: Semua masyarakat di Kampung Wasur sudah sama-sama saling mengetahui bahwa dong semua (mereka semua) saling pancuri (pencuri) kayu di tengah-tengah hutan. Warga masyarakat tidak memikirkan lagi batas-batas wilayah marga untuk mereka mencari kayu. Hutan-hutan yang ada sekarang di Kampung Wasur menurut Dominikus Kaize jauh sekali berbeda dibandingkan sebelumya. Hutan-hutan sekarang yang sebagian besar adalah wilayah adat tujuh marga besar Suku Marori Mengey sudah banyak yang terbakar saat musim kemarau penjang, gundul karena pohon-pohon besarnya banyak yang ditebang untuk mendapatkan uang bagi warga kampung. Tidak ada yang berani melarang penebangan kayu ini karena sudah menjadi sumber penghidupan bagi mereka. "Sensor kayu untuk dapat uang" begitu masyarakat Kampung Wasur sering menyebutnya.

Dominikus Kaize mengungkapkan bahwa jika ia bersama dengan anak-anaknya sedang di dalam hutan, mereka sering sekali mendengar suara-suara mesin sensor kayu yang membelah keheningan hutan. Sudah dapat dipastikan bahwa yang melakukan itu tidak lain adalah saudarasaudara mereka satu kampung di Wasur. Saya menyaksikan sendiri bagaimana warga kampung yang sebagian adalah anak-anak muda dan sebagian yang sudah tua, berjalan dengan motor berboncengan dengan membawa alat sensor siap-siap menuju hutan untuk menebang kayu. Di kios ujung kampung saya melihat dua motor berhenti untuk membeli bensin dan minyak untuk alat sensor. Jumlah mereka empat orang dan sudah siap dengan perlengkapan menuju ke dalam hutan. Saya melihat mereka sudah siap dengan jerigen-jerigen berisi bahan bakar mesin sensor dan yang berwarna merah adalah air. Tidak terlupakan saya melihat rantang-rantang tempat makanan dijinjing oleh dua diantara mereka. Berselang beberapa menit setelah dua motor ini berlalu dari kios, saya melihat dua mobil bak terbuka berwarna hitam dan putih merapat di depan kios. Ternyata mereka sedang menuju ke lokasi penebangan dan siap untuk mengangkutnya. Di depan kios juga terdapat banyak balok-balok kayu di pinggir jalan trans Papua yang siap untuk diangkut oleh para pendah kayu. Kayu-kayu tersebut disamping untuk keperluan memasak sehari-hari oleh masyarakat juga dipergunakan untuk memasak tahu di Kota Merauke.

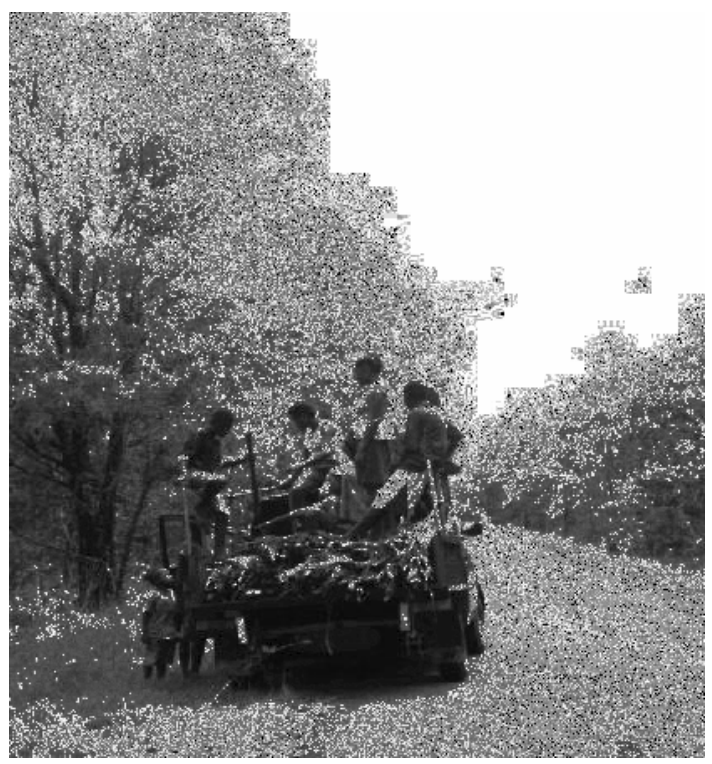

Gambar 6

Ruang-ruang ekologi masyarakat lokal makin sempit, salah satunya diakibatkan oleh kehadiran kawasan taman nasional yang merebut kawasan lingkungan alam mereka (foto: I Ngurah Suryawan)

Orang Marori dan Kanum di Kabupaten Merauke saat ini menghadapi situasi dilematis menyangkut pengelolaan sumber daya alam mereka. Kekayaan alam mereka di sekitar kampung, di wilayah-wilayah sakral dan pamali, terus menjadi incaran bukan hanya oleh perusahaan, namun oleh perusak lingkungan dengan menggunakan anak muda kampung sebagai kaki tangannya. Situasi yang sulit karena mereka harus merespon perubahan tersebut dengan cepat. Menghasilkan uang dengan cepat menjadi janji yang menggiurkan yang ditawarkan oleh orang-orang yang bertujuan untuk mengeruk kekayaan alam mereka.

Perburuan liar dan sensor (pemotongan) kayu adalah dua aktivitas yang begitu lekat dengan keseharian masyarakat Marori dan 
Kanum. Kedua aktivitas ini mewarnai kehidupan di kampung-kampung di kawasan Taman Nasional Wasur, Kabupaten Merauke, Papua secara umum. Penggerak aktivitas ini adalah para pengepul (pembeli) yang biasa mereka sebut berasal dari kota Merauke. Para pengepul ini didominasi oleh para pendatang yang akan dengan bersemangat berburu, mencari ikan, ataupun memotong kayu-kayu di wilayah kampong-kampung orang Marori dan Kanum. Para pengepul ini juga bisa hanya membeli dari para anak buah mereka yaitu anak muda ataupun warga di kampun-kampung yang sudah menjadi langganan mereka.

Yunus Maiwa, salah seorang tetua orang Kanum di Kampung Toemrauw mengungkapkan kisah menyedihkan yang terjadi di kampungnya. Kondisi kini yang terjadi adalah sungguh diluar dugaan. Saat ini yang terjadi di wilayah orang Kanum, khususnya di Kampung Tomerauw adalah perburuan yang sudah mulai melebar ke berbagai wilayah, termasuk daerah-daerah sacral dari beberapa marga. Perburuan dilakukan di daerah-daerah yang justru jauh dari kampung dan menjadi daerah pamali dan disakralkan oleh masyarakat Kanum di Kampung Tomerauw.

Yunus Maiwa dengan lirih mengungkapkan:

Sekarang perburuan ini melebar. Tidak ada tempat istirahat (dari perburuan). Binatang tidak tenang lari-lari terus karena dikejar manusia yang berburu. Padahal sebenarnya bintang masih ada di wilayah tersebut.

Situasi tersebut sungguh sangat disayangkan oleh masyarakat Kanum di Kampung Tomerauw. Perburuan yang dilakukan oleh manusia menyebabkan binatang yang biasanya tenang dan mencari makanan hingga mendekati perkampungan, kini menjauh karena takut akan diburu. Masyarakat meyakini bahwa binatang masih ada dan hidup berkembang biak dengan damai tanpa perburuan dari manusia.

Marga Maiwa berupaya untuk menjaga keseimbangan alam mereka, terutama untuk menjaga kekayaan sumber daya alam. Oleh karena itu, mereka memberlakukan Sasi untuk membatasi sementara waktu perburuan terhadap hewan yang sudah terlanjur berkembang marak di wilayah orang Kanum. Ritual Sasi yang sering dilakukan adalah Sasi Adat. Dalam Sasi Adat ini yang di Sasi adalah tempat-tempat yang menjadi tempat hidup dari hewan yang akan di Sasi. Lokasinya pun tidak terbatas dan membentang luas sesuai dengan perkiraan dari marga pemilik hak ulayat lokasi tersebut.

Lokasi yang tidak terbatas ini mempertimbangkan jangkauan dan juga berhubungan dengan kepemilikan tana ulayat yang menjadi lokasi Sasi tersebut. Tujuannya pun sangat tegas yaitu agar tempat yang menjadi lokasi Sasi tersebut tidak terganggu lagi dengan perburuan yang dilakukan oleh orang-orang dari luar orang Kanum maupun orang Kanum sendiri. Sangsinya juga sangat tegas yaitu pembayaran denda berupa Pohon Wati, babi, bahkan uang. Sangsi yang beragam ini juga adalah kesepakatan dari marga-marga yang melakukan Sasi tersebut. Begitu juga yang berlaku dengan waktu pelaksanaan yang juga disepakati oleh margamarga yang melakukan Sasi tersebut.

Perburuan yang liar dan tidak terkendali adalah alasan kuat lainnya untuk melaksanakan Sasi. Situasi perburuan liar ini sangat memprihatinkan bagi orang Kanum sehingga diperlukan langkah cepat untuk melakukan Sasi. Yunus Maiwa mengungkapkan bahwa perburuan hewan (kangguru, rusa, buaya, dan babi) dan ikan sudah menguasai semua tempat yang berada di wilayah orang Kanum. Masyarakat bukannya diam. Mereka sudah berusaha untuk mencari pemburu-pemburu tersebut, namunnya mencarinya setengah mati. Tetap saja berlangsung tanpa henti perburuan tersebut sehingga mengancam keberadaan dari hewan-hewan yang berada di wilayah orang Kanum.

Orang Kanum melakukan ritual Sasi dengan memberi tanda di suatu tempat. Tandanya berupa potongan tiang dari kayu yang tahan lama. Biasanya digunakan kayu besi karena akan tahan bertahun-tahun. Ini dilakukan karena pelaksanaan Sasi bisa berlangsung lebih dari satu tahun sesuai dengan kebutuhan dan keputusan dari masing-masing marga pemilik hak ulayat tempat berlangsungnya Sasi. Potongan kayu tersebut kemudian diikat dengan alang-alang dan daun kelapa. Potongan kayu panjang tersebut kemudian ditancapkan di wilayah-wilayah yang diberlakukan Sasi. Ada juga yang dipasang di pohon kelapa ciri dari Sasi tersebut sesuai dengan kondisi wilayah yang akan disasi. Jika tanda tersebut sudah terpasang, bisa dipastikan bahwa tempat tersebut sedang disasi menurut adat dari orang Kanum.

Proses pemberlakuan Sasi bisa berlangsung berbulan-bulan dan juga bertahun-tahun. Semuanya disepakati oleh marga-marga tentang batas waktu 
pelaksanaan Sasi. Yunus Maiwa menjelaskan, marga Maiwa pernah melakukan Sasi di kepala sungai di Rawa Biru. Pada saat itu Sasi dilakukan karena maraknya perburuan buaya yang berlangsung di kawasan Rawa Biru yang merupakan salah satu wilayah orang Kanum. Saat itu, terutam di kepala kali Rawa Biru, peruburuan buaya merambah hingga wilayahwilayah sacral yang dilindungi oleh orang Kanum.

Oleh karena itu, pemilik wilayah berkembang biaknya buaya di kepala kali Rawa Biru itu yaitu Kanum, Barkari, dan Ngelembu menyepakati untuk menutup wilayah tersebut dari perburuan buaya. Mereka sangat khawatir dengan terancamnya keberadaan buaya di wilayah Rawa Biru karena terus-menerus diburu. Sasi terhadap buaya ini diberlakukan selama tujuh tahun sehingga memberikan waktu untuk buaya berkembang biak. Masyarakat sekitar hanya boleh mencari ikan dan binatang saja di sekitar wilayah Rawa Biru.

Tidak hanya buaya saja yang menjadi perhatian masyarakat Kanum. Salah satu binatang yang selalu menjadi incaran para pemburu lainnya adalah rusa. Perburuan rusa sempat mengkhwatiran masyarakat saat banjir pemburu dari dari luar. Maka dari itu diberlakukan Sasi rusa selama enam bulan dan baru kemudian membukanya lagi pada saat musim kemarau. Masyarakat Kanum menilai bahwa keberadaan rusa mengalami keterancaman setelah tidak ada lagi rusa yang mencari makan di sekitar kampong mereka, Kampung Toemrauw khususnya. Ini jelas sesuatu yang aneh. Sebelumnya rusa-rusa tersebut mencari makan di sekitar kampung mereka, bahkan menonton kita makan. Namun keadaan tersebut berubah sangat cepat. Rusa-rusah sekarang tidak lagi mencari makan di dekat-dekat kampong karena sudah diburu hingga ke pedalaman. Situasi ini jelas sangat memprihatinkan.

Para pemburu yang sudah campur kiri kanan (bergabung antara para pendatang dengan orang lokal) inilah salah satunya yang menyebabkan terjamahnya tempat-tempat sakral yang merupakan ruang-ruang hidup dari orang Kanum secara keseluruhan di Toemrauw. Para pemburu dan juga pencari kayu akan menerobos tempat-tempat sakral tersebut dan kemudian merusaknya. Salah satu tempat sakral bagi marga Banggo yang merupakan pamali (dilarang) untuk dirusak adalah Репи. Репи ini adalah hutan sakral bagi marga Banggo. Di dalam hutan ini terdapat cabang-cabang kali yang menghubungkan dusun-dusun sagu di marga-marga lain Suku Kanum di wilayah Kampung Tomerauw.

Samuel Banggo mengisahkan, jika motormotor datang menyeruak keheningan kampung, maka bisa dipastikan bahwa para pemburu sudah tiba. Mereka akan menyambangi rumah penduduk kampung yang menjadi tukang jagal untuk berburu. Hal itu sering terjadi dan bisa dipastikan mereka akan berburu ke hutan-hutan dan dusun-dusun sakral beberapa marga Suku Kanum di Tomerauw. Hingga saat ini tempattempat untuk mereka menyambung hidup adalah di hutan-hutan. Mereka berburu untuk dikonsumsi sendiri maupun untuk dijual.

Situasi ketergantungan kepada hutanhutan dan mengeruk sumber daya alam yang ada di dalamnya sudah menjadi keresahan semua orang di Kampung Tomerauw. Tapi penduduk di kampung seperti tidak ada pilihan dan terus menggantungkan hidupnya dari berburu. Samuel Banggo menuturkan bahwa untuk menyambung hidup dengan mencari makan tidak cuma bisa dilakukan dengan berburu dan menghabiskan hewan-hewan dan juga kayu di hutan. Di samping itu, tentu saja merusak tempat-tempat sakral, dusun-dusun sagu dari nenek moyang untuk mencari makanan. Mencari makan bisa dilakukan dengan membuat kebun-kebun di pekarangan rumah untuk ditanami kumbili, ubi kayu, pisang, rica dan yang lainnya untuk kebutuhan hidup sehari-hari. Di samping itu, bisa juga menanam kelapa dan kemudian menjualnya atau mencari ikan gastor di rawarawa untuk kemudian dijual.

Tidak ada pilihan yang terbuka. Lebih tepatnya, orang-orang Marori dan Kanum tidak menciptakan pilihan yang menguntungkan. Mereka terpaku dengan kondisi yang ada dan ikut dalam permainan yang diciptakan oleh para pendatang yang hanya mempunyai kepentingan untuk mengeksploitasi alam mereka. Masyarakat seolah kekurangan bahasa dan daya untuk merespon perubahan yang tiba-tiba ada di depan mata mereka.

\section{Penutup}

Berdiri di Tong Pu Kebun adalah ungkapan optimisme bahwa orang Marori dan Kanum tegak berdiri dengan identitas dan budaya di tanah mereka, dan kebun yang menjadi sumber penghidupan. Cikal bakal itu semua adalah pada 
keberadaan bahasa dan nilai-nilai kebudayaan yang menyertainya. Totalitas pengetahuan kebudayaan tersebut adalah identitas yang menjadi modal sosial bagi generasi penerus orang Marori dan Kanum. Oleh karena itu, sangat diperlukan inisiatif-inisiatif lokal untuk melakukan dokumentasi bahasa dan nilai-nilai pengetahuan di dalamnya. Salah satu yang sangat penting itu adalah dokumentasi bahasa yang berhubungan dengan lingkungannya.

Bahasa dan kebudayaan adalah identitas yang menegakkan harga diri seseorang. Tantangan perubahan sosial budaya bagi orang Marori dan Kanum membutuhkan pondasi untuk melangkah. Orang Marori dan Kanum memerlukan kesiapan untuk menempatkan diri di tengah perubahan yang hadir di depan mata mereka. Masyarakat lokal Papua secara umum memerlukan ruang-ruang untuk mengembangkan sikap dalam menanggapi perubahan tersebut. Namun, menanggapi perubahan memerlukan sebuah pondasi berpijak dan juga kesiapan. Mereka harus terlibat dalam perubahan, jangan justru menjauh dan frustasi bahkan menuntut agar nilai-nilai kehidupannya dianggap suci dan tidak mungkin diubah.

Orang Marori dan Kanum memerlukan refleksi mendalam bersumber dari nilai-nilai budaya dan pengetahuan lokal yang diwariskan para leluhur mereka. Terkhusus dalam usaha pengelolaan sumber daya alam, dokumentasi bahasa-bahasa lokal dan nilai-nilai budayanya, adalah pondasi yang kuat untuk merefleksikan diri ke depan dalam memanfaatkan sumber daya alam. Usaha refleksi yang dimaksudkan adalah menarik pelajaran dari masa lampau, kondisi kini, dan meneropong untuk masa depan. Tentu ini bukanya perspektif romantik yang mengenang cerita masa lalu tanpa mempertimbangkan perubahan pesat yang terjadi. bahasa ibu.

Mari berdiri di tong $p u$ kebun, di tong $p u$

\section{Daftar Pustaka}

Broek OFM, Drs. Theo van den. (2002). Mengatasi Keterpecahan yang Melumpuhkan. Jayapura: SKP Keuskupan Jayapura dan LSPP Jakarta, 2002.

Giay, Benny. 1996, "Pembangunan Irian Jaya dalam Perspektif Agama, Budaya, dan Antropologi" makalah dalam Simposium Masyarakat dan Pembangunan di daerah
Irian Jaya yang dilaksanakan BPC GMKI Jayapura tahun 1996.

Henley, David, Jamie Davidson dan Sandra Moniaga (editor). (2010). Adat dalam Politik Indonesia, Jakarta: KITLV Jakarta dan Yayasan Obor Indonesia.

Iskandar, Johan. (2016). "Etnobiologi dan Keragaman Budaya di Indonesia" dalam Jurnal Umbara: Indonesian Journal of Anthropology, Jurusan Antropologi Universitas Padjajaran Bandung, Vol 1 (1) Juli 2016.

Laksono, P.M. (2002). "Tanpa Tanah, Budaya Nir-Papan, Antropologi AntahBerantah" dalam Lounela, Anu dan R. Yando Zakaria (editor). (2002). Berebut Tanah: Beberapa Kajian Berperspektif Kampus dan Kampung, Yogyakarta: Insist, Jurnal Antropologi Indonesia dan Karsa.

Laksono, P.M. (2011). "Ilmu-ilmu Humaniora, Globalisasi, dan Representasi Identitas". Pidato yang disampaikan pada Peringatan Dies Nataliske-65 Fakultas Ilmu Budaya Universitas Gadjah Mada Yogyakarta, 3 Maret 2011.

Lounela, Anu dan R. Yando Zakaria (editor). (2002). Berebut Tanah: Beberapa Kajian Berperspektif Kampus dan Kampung, Yogyakarta: Insist, Jurnal Antropologi Indonesia dan Karsa.

Muliawan, Muhamad Budi. (2013). "Kearifan Tradisional Perlindungan dan Pemanfaatan Sumberdaya Hutan oleh Suku Kanume di Taman Nasional Wasur" Skripsi di Departemen Konservasi Sumberdaya Hutan dan Ekowisata Fakultas Kehutanan, Institut Pertanian Bogor, Indonesia.

Patriana, Ratna. Soeryo Adiwibowo, Rilus A. Kinseng, dan Arif Satria. (2016). "Perubahan Kelembagaan dalam Pengelolaan Sumberdaya Laut Tradisional (Kasus Kelembagaan Sasi di Kaimana)" dalam Sodality: Jurnal Sosiologi Pedesaan, Desember 2016, hal 257-264.

Rahman, Noer Fauzi. (2015). "Memahami Reorganisasi Ruang dalam Perspektif Politik Agraria" dalam Jurnal Bhumi STPN (Sekolah Tinggi Pertanahan Nasional) Vo.1 No.1 Mei 2015.

Ramstedt, Martin dan Fadjar Ibnu Thufail (editor). (2011). Kegalauan Identitas: 
Agama, Etnisitas, dan Kewarganegaraan pada masa Pasca-Orde Baru, Jakarta: PSDR-LIPI, Max Planck Institute for Social Anthropology dan Grasindo.

Rutherford, Danylin. (2000). "The White Edge of the Margin: Textuality and Authority in Biak, Irian Jaya, Indonesia" dalam American Etnologist Vol. 27, No. 2 (May, 2000), pp. 312-339

Scott, James C. (1995). State Simplifications, Some Applications to Southeast Asia. Amsterdam: CASA.

Suryawan, I Ngurah. (2017). "Draft narasi penelitian lapangan di Kampung Wasur April 2016" dalam skema Major Documentation Project, MDP0336 (20162017) dari ELDP (Endagered Language Development Project) SOAS London yang berjudulThe Endangered Papuan Languages of Merauke-Indonesia: ethnobiological and linguistic documentation.

Suryawan, I Ngurah. (2017a). Monograf "Dinamika Etnoekologi dan Transformasi Orang Marori dan Kanum di Kabupaten Merauke, Papua" dalam skema Major Documentation Project, MDP0336 (2016-2017) dari ELDP (Endagered Language Development Project) SOAS London yang berjudul The Endangered Papuan Languages of Merauke-Indonesia: ethnobiological and linguistic documentation.

Suryawan, I Ngurah. (2017b). Draft buku "Ruang Hidup yang Redup: Etnografi Orang Marori dan Kanum dengan Ekologinya" dalam skema Major Documentation Project, MDP0336 (2016-2017) dari ELDP (Endagered Language Development Project) SOAS London yang berjudul The Endangered Papuan Languages of Merauke-Indonesia: ethnobiological and linguistic documentation
Timmer, Jaap. (2013). "Melampaui Kulturalisme", Pengantar dalam I NgurahSuryawan, Jiwa yang Patah. Yogyakarta: Kepel Press dan Jurusan Antropologi Universitas Papua (UNIPA) Manokwari, Papua Barat.

Tsing, A.L. (2005). Friction: An Ethnography of Global Connection. Princeton and Oxford: Princeton University Press.

Wattimena, Marthinus Corneles. (2013). "Perspektif Tempat Penting Suku Malind sebagai arahan dalam penyusunan detail tata ruang wilayah Kabupaten Merauke" Tesis pada Sekolah Pascasarjana Institut Pertanian Bogor.

Yarman. (2012). "Interaksi Masyarakat Suku Asli (Masyarakat Adat) dengan Masyarakat pendatang dan impliaksinya pada rancangan pengelolaan Taman Nasional Wasur" Tesis pada Sekolah Pascasarjana Institut Pertanian Bogor

Zollner, Zilfred. (2006). Hak-hak Ekonomi, Sosial dan Budaya di Papua Barat: Studi Realita Sosial dan Perspektif Politis. Jakarta: Pustaka Sinar Harapan bekerjasama dengan The Evangelical Church in the Rhineland dan Gereja Kristen Injili di Tanah Papua. 
